\title{
Control of human pathogenic Yersinia enterocolitica in minced meat: Comparative analysis of different interventions using a risk assessment approach
}

\author{
Van Damme, I.; De Zutter, L.; Jacxsens, L.; Nauta, Maarten
}

\section{Published in:}

Food Microbiology

Link to article, DOI:

10.1016/j.fm.2016.12.006

Publication date:

2017

Document Version

Peer reviewed version

Link back to DTU Orbit

Citation (APA):

Van Damme, I., De Zutter, L., Jacxsens, L., \& Nauta, M. (2017). Control of human pathogenic Yersinia enterocolitica in minced meat: Comparative analysis of different interventions using a risk assessment approach. Food Microbiology, 64, 83-95. https://doi.org/10.1016/j.fm.2016.12.006

\section{General rights}

Copyright and moral rights for the publications made accessible in the public portal are retained by the authors and/or other copyright owners and it is a condition of accessing publications that users recognise and abide by the legal requirements associated with these rights.

- Users may download and print one copy of any publication from the public portal for the purpose of private study or research.

- You may not further distribute the material or use it for any profit-making activity or commercial gain

- You may freely distribute the URL identifying the publication in the public portal 


\section{Accepted Manuscript}

Control of human pathogenic Yersinia enterocolitica in minced meat: Comparative analysis of different interventions using a risk assessment approach

I. Van Damme, L. De Zutter, L. Jacxsens, M.J. Nauta

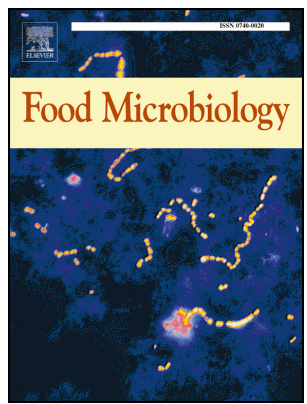

PII: S0740-0020(16)30772-9

DOI: 10.1016/j.fm.2016.12.006

Reference: $\quad$ YFMIC 2693

To appear in: Food Microbiology

Received Date: 21 September 2016

Revised Date: 8 December 2016

Accepted Date: 12 December 2016

Please cite this article as: Van Damme, I., De Zutter, L., Jacxsens, L., Nauta, M.J., Control of human pathogenic Yersinia enterocolitica in minced meat: Comparative analysis of different interventions using a risk assessment approach, Food Microbiology (2017), doi: 10.1016/j.fm.2016.12.006.

This is a PDF file of an unedited manuscript that has been accepted for publication. As a service to our customers we are providing this early version of the manuscript. The manuscript will undergo copyediting, typesetting, and review of the resulting proof before it is published in its final form. Please note that during the production process errors may be discovered which could affect the content, and all legal disclaimers that apply to the journal pertain. 


\section{ACCEPTED MANUSCRIPT}

1

2

3

4 Van Damme I. ${ }^{a *}$, De Zutter L. ${ }^{a}$, Jacxsens L. ${ }^{b}$, Nauta M.J. ${ }^{c}$

5

6

7

8

9

10

lieven.dezutter@ugent.be) Belgium (liesbeth.jacxsens@ugent.be) Bygade 19, DK-2860 Søborg, Denmark (maana@food.dtu.dk) mail: inge.vandamme@ugent.be; Tel.: +329264 7341

Control of human pathogenic Yersinia enterocolitica in minced meat: Comparative analysis of different interventions using a risk assessment approach

${ }^{a}$ Department of Veterinary Public Health and Food Safety, Faculty of Veterinary Medicine, Ghent University, Salisburylaan 133, B-9820 Merelbeke, Belgium (inge.vandamme@ugent.be;

${ }^{b}$ Laboratory of Food Microbiology and Food Preservation, Department of Food Safety and Food Quality, Faculty of Bioscience Engineering, Ghent University, Coupure Links 653, B-9000 Ghent,

${ }^{c}$ National Food Institute, Technical University of Denmark, Research Group for Risk-Benefit, Mørkhøj

* Corresponding author: Inge Van Damme; Department of Veterinary Public Health and Food Safety, Faculty of Veterinary Medicine, Ghent University, Salisburylaan 133, B-9820 Merelbeke, Belgium; e- 


\section{Abstract}

This study aimed to evaluate the effect of different processing scenarios along the farm-to-fork chain on the contamination of minced pork with human pathogenic $Y$. enterocolitica. A modular process risk model (MPRM) was used to perform the assessment of the concentrations of pathogenic $Y$. enterocolitica in minced meat produced in industrial meat processing plants. The model described the production of minced pork starting from the contamination of pig carcasses with pathogenic $Y$. enterocolitica just before chilling. The endpoints of the assessment were (i) the proportion of $0.5 \mathrm{~kg}$ minced meat packages that contained pathogenic $Y$. enterocolitica and (ii) the proportion of $0.5 \mathrm{~kg}$ minced meat packages that contained more than $10^{3}$ pathogenic $Y$. enterocolitica at the end of storage, just before consumption of raw pork or preparation. Comparing alternative scenarios to the baseline model showed that the initial contamination and different decontamination procedures of carcasses have an important effect on the proportion of highly contaminated minced meat packages at the end of storage. The addition of pork cheeks and minimal quantities of tonsillar tissue into minced meat also had a large effect on the endpoint estimate. Finally, storage time and temperature at consumer level strongly influenced the number of highly contaminated packages.

Keywords: Yersinia enterocolitica, minced meat, risk assessment, pork, interventions 


\section{Introduction}

As pork is the second most consumed meat worldwide (OECD, 2016), an effective control of zoonotic agents transferred via pork is of major importance to limit the public health risk of zoonotic diseases. Due to the frequent finding of human pathogenic Yersinia enterocolitica in pigs and pork compared to other food producing animals and food products, and the high genetic relatedness of human and porcine strains, pork is considered the main source of human pathogenic $Y$. enterocolitica. As such, 77\% of $Y$. enterocolitica cases in Europe may be attributed to the consumption of pork (Fosse et al., 2008). The consumption of raw minced meat may be of particular importance in transmitting pathogenic $Y$. enterocolitica to humans as Rosner et al. (2012) found that $34 \%$ of yersiniosis cases in Germany had consumed raw minced pork in the seven days preceding illness compared to $12 \%$ of the control group.

With 6,471 confirmed cases in 2013, yersiniosis remains the third most commonly reported zoonosis in the European Union. Over $98 \%$ of cases is caused by human pathogenic Yersinia enterocolitica (EFSA and ECDC, 2015), the majority of strains belonging to bioserotype 4/O:3 (EFSA, 2009). The main reservoirs of these strains are domestic pigs, which can asymptomatically carry the pathogens in lymph nodes, tonsils and the intestinal tract (Laukkanen-Ninios et al., 2014a), resulting in the spread to the carcass during different steps in the slaughter process (Borch et al., 1996). The presence of pathogenic $Y$. enterocolitica in the intestines and especially the tonsils is strongly associated with carcass contamination (Van Damme et al., 2015; Vilar et al., 2015) and carcass contamination has been shown to differ according to the location on the carcass, with more positive samples found near the head region and sternum than other areas of the carcass (Laukkanen et al., 2010; Van Damme et al., 2015).

Although the species $Y$. enterocolitica is very heterogeneous, the presence of virulence genes in the most common types of pathogenic Y. enterocolitica seems to be homogeneous (Murros et al., 2016; Schneeberger et al., 2015). As a result, exposure to these pathogenic types may be more relevant for public health, rather than specific virulence traits of certain strains. Therefore, identification of the process steps along the farm-to-fork pathway that have the largest influence on this exposure may be the most effective way in reducing the public health risk of yersiniosis, prospecting the development of targeted control measures. Quantitative microbial risk assessment (QMRA) has emerged in the area of food safety as a comprehensive and systematic approach for addressing the risk of microbial hazards in the food chain and can be used to assess the impact of control strategies or interventions (Havelaar et al., 2008; Møller et al., 2015). Using the Modular Process Risk Model (MPRM) methodology as proposed by Nauta (2008), the food production pathway is described by subdividing the chain in different modules that each represent a basic process. These basic processes 
include microbial (growth or inactivation) and food handling processes (cross-contamination, removal, partitioning and mixing), by which the changes in prevalence, concentration and unit can be modelled. The output of one module then serves as the input for the following module. This structured approach allows a structured analysis of the food chain, which gives new insights in the complex process of food production and can identify crucial data gaps.

The objective of this study was to model the spread of pathogenic $Y$. enterocolitica contamination during the production of minced meat and to evaluate the effect of different intervention scenarios during minced meat production on human exposure via raw minced pork. Therefore, a food chain modelling approach was applied to assess the exposure of human pathogenic $Y$. enterocolitica through industrially produced minced meat using the MPRM methodology. First a baseline model was built describing the current processing practices and changes in prevalence and concentrations during the process. Next, alternative scenarios were defined to evaluate the effects of potential interventions. As, to our knowledge, there is no dose response model available for $Y$. enterocolitica and no accurate data on raw minced meat consumption could be found, the endpoint of the assessment was not the exposure or the health risk but (A) the proportion of contaminated $0.5 \mathrm{~kg}$ minced meat packages with pathogenic $Y$. enterocolitica and (B) the proportion of $0.5 \mathrm{~kg}$ minced meat packages that contained more than $10^{3}$ pathogenic $Y$. enterocolitica at the end of storage, just before consumption of raw minced pork or preparation. To identify the most important data gaps, uncertainties were studied by comparative scenario analyses.

\section{Material and Methods}

\subsection{Description of the food pathway and model implementation}

An overview of the pathway used in the model is shown in Figure 1. A general overview of the model and a detailed description of the distributions and parameters used are shown in Table 1 and 2, respectively.

The entire model was simulated with Monte Carlo techniques (100,000 iterations) using @Risk software (version 7.5.0., Palisade Corporation, Newfield, NY, US). By the lack of a health risk estimate, the alternative main outputs of the model were point estimates of the prevalence (proportion of 0.5kg packages containing one or more pathogenic $Y$. enterocolitica) and/or the proportion of highly contaminated minced meat packages (containing $>10^{3}$ pathogenic $Y$. enterocolitica per $0.5-\mathrm{kg}$ package). To evaluate the effect of alternative scenarios, the value of one or more model parameters was changed and the corresponding endpoint estimate was compared to that of the baseline scenario. Different scenarios were compared by calculating the $\log _{10}$ of the relative proportions (the 
quotient of the endpoint estimate of an alternative scenario and the endpoint estimate of the baseline scenario), as e.g. in Møller et al. (2015).

\subsection{The baseline model}

\subsubsection{Input data - initial contamination of carcasses}

The prevalence and concentration of human pathogenic $Y$. enterocolitica on pig carcasses were used as input for the model and were based on the results of a Belgian study describing the contamination of pork carcasses with pathogenic $Y$. enterocolitica after evisceration before cooling (Van Damme et al., 2015). The study detected $Y$. enterocolitica bioserotype 4/O:3 on the sternal region (breast cut and surrounding skin) of $16.4 \%$ of the carcasses, which was the value used as the initial prevalence of carcasses $\left(P_{\text {initial }}\right)$. Quantitative and semi-quantitative concentration data of pathogenic $Y$. enterocolitica at the sternal region were obtained by analysing different subsamples with different isolation methods. The R package "fitdistrplus" was used to fit a normal distribution to the censored data using the "fitdistcens" function (Pouillot and Delignette-Muller, 2010). The resulting normal distribution of the $Y$. enterocolitica concentration on pork carcasses was used as input for the model $\left(C_{\text {initial }} \sim\right.$ Normal $(-2.565 ; 0.736)$ in $\log _{10} \mathrm{CFU} / \mathrm{cm}^{2}$, with meaning that it is a random sample from the distribution). As $\mathrm{P}_{\text {inital }}$ was based on the combined results of different detection methods from which the $C_{\text {initial }}$ distribution was derived, the distribution was truncated at a minimum value of $-1.85 \log _{10}$ $\mathrm{CFU} / \mathrm{cm}^{2}$, which was the limit of detection of the most sensitive detection method. The final (truncated) distribution had a mean of $-1.46 \log _{10} \mathrm{CFU} / \mathrm{cm}^{2}$ and standard deviation of 0.33 .

\subsubsection{Inactivation and growth during carcass chilling and cold storage}

Blast chilling, during which the carcass surface is frozen, was considered to cause a $0.6 \log _{10}$ reduction in pathogenic $Y$. enterocolitica concentrations $\left(I_{c c}\right)$, according to data of King et al. (2012) who evaluated the effect of freezing on $Y$. enterocolitica numbers on pig organs. When the concentration after inactivation $\left(\mathrm{N}_{\mathrm{cci}}\right)$ was below $1 \mathrm{CFU} / 2000 \mathrm{~cm}^{2}$, the carcass was considered to be pathogenic $Y$. enterocolitica negative and growth after the blast chilling step was not allowed in the model.

After inactivation during blast chilling, Y. enterocolitica was assumed to grow during conventional air chilling and cold storage of carcasses at $4^{\circ} \mathrm{C}$. The doubling time for the growth model during carcass cold storage $\left(D_{c c g}\right)$ was set at $10.0 \mathrm{~h}$, based on ComBase Predictor results (http://combase.cc) using a $\mathrm{pH}$ of 5.8 , Aw value of 0.997 , and temperature of $4^{\circ} \mathrm{C}$ as input values. The lag phase $\left(\lambda_{\mathrm{ccg}}\right)$ for the growth model was set at $24 \mathrm{~h}$ and the maximum growth was never allowed to result in concentrations higher than $7 \log _{10} \mathrm{CFU} / \mathrm{cm}^{2}$ (van Netten et al., 1997). Carcasses from pigs that were slaughtered on Mondays to Thursdays were assumed to be processed the next day and pigs 
slaughtered on Fridays were processed on Monday, resulting in a cold storage time (Time $\mathrm{ccg}_{\text {cg }}$ ) of respectively $20 \mathrm{~h}$ and $68 \mathrm{~h}$ in $80 \%$ and $20 \%$ of the iterations. The concentration of pathogenic $Y$. enterocolitica on carcasses after growth during cold storage, $\mathrm{N}_{\mathrm{ccg}}$, was determined:

$$
N_{c c g}=N_{c c i} \times 2 \frac{\text { Time }_{c c g}-\lambda_{c c g}}{D_{c c g}}
$$

When $\lambda_{\text {ccg }}$ was higher than Time $e_{c c g}$, no growth was allowed, so $\mathrm{N}_{\mathrm{ccg}}$ was equal to the number of CFU after blast chilling $\left(\mathrm{N}_{\mathrm{cci}}\right)$.

\subsubsection{Cutting, derinding, grinding and packaging at the meat processing plant}

The model for grinding was based on practices of a representative large minced meat producing company in Belgium. In the baseline model, a batch consisted of $900 \mathrm{~kg}$ minced meat and contained $34 \%$ pork bellies (weight/weight percent, w:w). The remaining ingredients (which may be beef, eggs, herbs, and/or other pork cuts) were assumed to have no contribution to contamination with pathogenic $Y$. enterocolitica. Although other pork cuts, such as shoulder cuts, are also frequently used for the production of minced meat, the contribution of these cuts was not included in the model due to the lack of sufficient reliable data. The baseline model thus assumed that bellies were the sole source of pathogenic $Y$. enterocolitica contamination.

The number of pathogenic $Y$. enterocolitica on a contaminated belly cut $\left(N_{b c}\right)$ was determined using the number of CFU on the carcass after growth during cold storage and assuming a total surface of $2000 \mathrm{~cm}^{2}$ (approximately $20 \mathrm{~cm} \times 50 \mathrm{~cm}$ on both sides). After derinding, the baseline model assumed that half of the bacteria were removed. The prevalence of pathogenic $Y$. enterocolitica on belly cuts was assumed to be the same as the initial contamination of carcasses $\left(P_{b d r}=P_{\text {initial }}\right)$.

Assuming a weight of pork bellies of $W_{b c}=7.5 \mathrm{~kg}$ each, the number of pork bellies within one batch was calculated $\left(n_{b b}\right)$. The number of pathogenic $Y$. enterocolitica contaminated pork bellies per batch was determined using $n_{p b b} \sim$ Binomial $\left(n_{b b} ; P_{b d r}\right)$. The total number of bacteria per contaminated pork belly $\left(N_{b d r, i}\right)$ was simulated for each positive belly $i\left(i=1 . . n_{p b b}\right)$ included in the batch (taking a random sampling from $C_{\text {initial }}$ for each positive belly). All bellies that were used within one batch of minced meat were assumed to originate from pigs slaughtered on the same day, so the time between slaughter and cooling (Time ${ }_{\mathrm{ccg}}$ ) remained constant for all bellies within the same batch. The numbers of pathogenic $Y$. enterocolitica on each of the positive bellies were added to determine the total number of pathogenic $Y$. enterocolitica in a batch of minced meat $\left(N_{m b}\right)$ :

$$
N_{m b}=\sum_{i=1}^{n_{p b b}} N_{b d r, i}
$$


The weight of individual minced meat packages $\left(\mathrm{W}_{\mathrm{mp}}\right)$ was assumed to be $0.5 \mathrm{~kg}$. Pathogenic $Y$. enterocolitica were assumed to be homogeneously distributed in a batch to calculate the number of pathogenic $Y$. enterocolitica in one $0.5-\mathrm{kg}$ minced meat package $\left(\mathrm{N}_{\mathrm{mp}}\right)$ (Nauta, 2005).

\subsubsection{Storage at the meat processing plant, retail and consumer level}

As there is no specific secondary growth model available for pathogenic $Y$. enterocolitica in minced meat at different temperatures, the growth at retail and consumer level was modelled using ComBase data (www.combase.cc). Hereby, the maximum growth rate (in $\log _{10} \mathrm{CFU} / \mathrm{h}$ ) was determined for temperatures varying between 0 and $15^{\circ} \mathrm{C}$ (using $1^{\circ} \mathrm{C}$ steps) for a pH of 5.8 and $\mathrm{NaCl}$ concentration of $1 \%$. The percentage of $\mathrm{CO}_{2}$ was set at $30 \%$ to represent MAP packaging. Fitting a regression line through the temperature - growth rate values obtained $\left(R^{2}=0.9992\right)$, resulted in an equation that was used to calculate $\mu_{\max }$ according to the temperature (Table 2 ).

To represent storage in the meat processing plant, transport and retail, the temperature $\left(\mathrm{Temp}_{\mathrm{rg}}\right)$ and time (Time ${ }_{\mathrm{rg}}$ ) was set at $4^{\circ} \mathrm{C}$ and $24 \mathrm{~h}$, respectively. To represent storage at consumer level, the temperature $\left(\mathrm{Temp}_{\mathrm{cg}}\right)$ was based on data from the Belgian Food Consumption Survey of 2004, in which the temperature of home refrigerators was determined (Devriese et al., 2006), resulting in a Pert distribution defined by the quartiles, 5,7 and $9^{\circ} \mathrm{C}$. Pathogenic $Y$. enterocolitica were considered not to grow below $0^{\circ} \mathrm{C}$. The time during which minced meat was stored (Time $\mathrm{cg}_{\mathrm{cg}}$ ) was based on results of Swedish consumers (Marklinder et al., 2004), resulting in a Pert distribution with most likely one day, a minimum of zero and maximum of four days. The final number of pathogenic $Y$. enterocolitica in $0.5-\mathrm{kg}$ minced meat packages just before consumption/preparation was calculated as

$$
\left.N_{c g}=N_{m p} \times 10^{\left(\mu_{m a x}, c g\right.} \times \text { Time }_{c g}+\mu_{\max , r g} \times \text { Time }_{r g}\right)
$$

The endpoint estimates were the proportion of $0.5-\mathrm{kg}$ minced meat packages that contained $\geq 1$ pathogenic $Y$. enterocolitica and the proportion of packages that contained $\geq 1000$ pathogenic $Y$. enterocolitica per 0.5-kg minced meat package.

\subsection{Alternative scenarios}

Alternative scenarios of the model were run and compared to the baseline model. Some of these alternative scenarios represent realistic modifications of processing, which can for example be implemented as interventions (2.3.1 - 2.3.3). Other alternative scenarios are evaluated in an uncertainty analysis, to study the uncertainty attending parameter values and model assumptions (2.3.4; as e.g. in Nauta et al. (2007)). An overview of the different parameters that were modified to evaluate alternative scenarios is shown in Tables 3 to 6. 
Alternative scenarios for initial carcass contamination were analysed using a prevalence $\left(P_{\text {initial }}\right)$ of $7.5 \%$ and $37.5 \%$ and concentrations $\left(C_{\text {initial }}\right)$ that had a mean concentration of $0.5 \log _{10}$ lower or higher than in the baseline model, to represent the 'best' and 'worst' slaughterhouses regarding pathogenic $Y$. enterocolitica contamination, respectively (Van Damme et al., 2015). Six different scenarios were evaluated: a lower prevalence (7.5\%) but baseline concentrations (scenario A1); a lower concentration but baseline prevalence (scenario A2); a lower prevalence and a lower concentration (scenario A3); a higher prevalence but baseline concentrations (scenario A4); a higher concentration but baseline prevalence (scenario A5); and a higher prevalence and higher concentration (scenario A6).

To simulate a slaughterhouse that only applied conventional air chilling (no prior blast chilling; scenario A7), a $0.1 \log _{10}$ reduction during chilling was assumed ( $\left.I_{c c}\right)$, which is based on the mean reduction of $Y$. enterocolitica after chilling of pig organs to a an internal temperature of $4^{\circ} \mathrm{C}$ (King et al., 2012). The use of steam condensation was evaluated based on the reductions observed by Smulders et al. (2012) when applying steam of $65^{\circ} \mathrm{C}$ for $18 \mathrm{~s}$ on pork skin, and was followed by a reduction to simulate either conventional chilling (scenario A8) or blast chilling (scenario A9). The effect of applying lactic acid treatment $\left(2 \%\right.$ for $10 \mathrm{~s}$ at $\left.40-50^{\circ} \mathrm{C}\right)$, combined with blast chilling or conventional air chilling, was simulated using a reduction of 0.7 and 1.6, respectively (King et al., 2012) (scenario A10 and A11). The reduced growth during carcass cold storage after lactic acid treatment was simulated using a lag phase $\left(\lambda_{\mathrm{ccg}}\right)$ of $48 \mathrm{~h}$ and doubling time $\left(D_{\mathrm{ccg}}\right)$ of $12.4 \mathrm{~h}$ based on results of van Netten et al. (1997), after applying $2 \%$ lactic acid (at $37^{\circ} \mathrm{C}$ for 120 ) on pork skin.

The cold storage time of carcasses ( Time $_{\mathrm{ccg}}$ ) was set at either $68 \mathrm{~h}$ or $20 \mathrm{~h}$ to represent the production of minced meat on Monday (from carcasses slaughtered on Friday; scenario A12) or minced meat produced on Tuesday-Friday (from carcasses slaughtered on Monday-Thursday; scenario A13).

\subsubsection{Addition of head meat and tonsillar tissue during grinding and batch size effect}

The effect of the inclusion of head meat for the production of minced meat was simulated at different levels (1\%, 10\%, and 50\% w:w; scenarios B1 , B2, and B3, respectively). As input data, prevalence and count data of human pathogenic $Y$. enterocolitica on the mandibular region of carcasses before chilling were obtained from Van Damme et al. (2015). A distribution was fitted through the censored count data (see 2.2.1), resulting in a lognormal distribution for $C_{\text {initial, }}$ with a mean of -0.578 and standard deviation of $1.26 \log _{10} \mathrm{CFU} / 100 \mathrm{~cm}^{2}$. The distribution was truncated at $0.15 \log _{10} \mathrm{CFU} / 100 \mathrm{~cm}^{2}$ (the lower limit of the most sensitive isolation method), yielding a new distribution with a mean of $0.93 \log _{10} \mathrm{CFU} / 100 \mathrm{~cm}^{2}$ and standard deviation of 0.64 . All pathogenic $Y$. enterocolitica on one head meat cut were assumed to originate from the carcass at the surface (100 
$\mathrm{cm}^{2}$ ) of the mandibular region. The same steps during the chilling and cold storage of carcasses were applied as for the sternal region. Carcasses containing less than $0 \log _{10} \mathrm{CFU} / 100 \mathrm{~cm}^{2}$ after blast chilling $\left(C_{m c i}\right)$ were considered negative. The number of pathogenic $Y$. enterocolitica positive head meat cuts per batch $\left(n_{\text {phb }}\right)$ was calculated similar to the pork bellies, assuming a weight of an individual cheek of $75 \mathrm{~g}\left(\mathrm{~W}_{\mathrm{hm}}\right)$, and a prevalence of $28.9 \%\left(\mathrm{P}_{\text {initial, } \mathrm{m}}\right)$. The number of cfu per head meat cut was simulated for each positive cut separately, starting each time from $C_{\text {initial, } m}$. The numbers of pathogenic $Y$. enterocolitica on positive head meat cuts were added to the numbers on pork bellies to determine the total number of pathogenic $Y$. enterocolitica per batch of minced meat $\left(N_{m b}\right)$.

The addition of tonsillar tissue (scenarios B4-B6) was simulated using a prevalence $\left(P_{\text {initial, }}\right)$ of pathogenic $Y$. enterocolitica in pig tonsils during slaughter of $44.3 \%$ and an initial concentration $\left(C_{\text {initial, }}\right)$ with a minimum of $1.00 \log _{10} \mathrm{CFU} / \mathrm{g}$, most likely of $4.00 \log _{10} \mathrm{CFU} / \mathrm{g}$ and a maximum of 5.91 $\log _{10}$ CFU/g (Van Damme et al., 2015). Inactivation and growth during carcass chilling and cold storage was included as described before. Numbers were modelled for each individual positive tonsil and were added to the total number of pathogenic $Y$. enterocolitica from pork bellies to calculate the total number of pathogenic $Y$. enterocolitica per batch of minced meat $\left(\mathrm{N}_{\mathrm{mb}}\right)$. As alternative scenarios, we evaluated the addition of one piece of tonsillar tissue of $1 \mathrm{~g}$ (scenario B4), one piece of tonsillar tissue of $10 \mathrm{~g}$ (scenario B5), and 10 pieces of tonsillar tissue (of 10 different pigs) of $1 \mathrm{~g}$ each (scenario B6).

Besides a batch weight of $900 \mathrm{~kg}$ in the baseline scenario, the effect of smaller and larger minced meat batches were simulated by changing $W_{b}$ to $140 \mathrm{~kg}$ and $1500 \mathrm{~kg}$ in the alternative scenarios $B 7$ and $\mathrm{B} 8$, respectively.

\subsubsection{Consumer storage practices}

Alternative scenarios for consumer storage (C1-C9) were evaluated by replacing Temp $\mathrm{co}_{\mathrm{cg}}$ or Time $\mathrm{Cg}_{\mathrm{cg}}$ by different fixed values $\left(4^{\circ} \mathrm{C}, 7^{\circ} \mathrm{C}, 10^{\circ} \mathrm{C}\right.$ and $15^{\circ} \mathrm{C}$ for Temp $p_{\mathrm{cg}}$ and $0,1,2,3$, and 4 days for Time $\left.\mathrm{cg}_{\mathrm{cg}}\right)$. The effect of consumer storage scenarios was evaluated for both MAP packaging and storage under ambient atmosphere. Storage under ambient atmosphere was simulated by changing the formulas for $\mu_{\max }$ both at retail and consumer level (Table 5). The formula was created using ComBase data as described before, but omitting the parameter " $\mathrm{CO}_{2}$ ".

For simulation of MAP packages that are consumed at the use-by date (scenarios C10 and C11), a shelf-life of 9 days was assumed based on company information. Storage of minced meat at consumer level until the use-by date (scenario $\mathrm{C10}$ ) was simulated setting the storage time at consumer level at 7 days. For simulation of MAP packages that are sold and consumed/prepared at 
the use-by date (scenario C11), the storage time at retail $\left(\mathrm{Time}_{\mathrm{rg}}\right.$ ) was set at 9 days and storage time at consumer level (Time ${ }_{\mathrm{cg}}$ ) was set at 0 days.

\subsubsection{Uncertainty analysis}

Uncertainty analyses were performed by estimating the prevalence and proportion of packages containing more than $3 \log _{10}$ CFU by changing one parameter value in the model to a value that represents the low or high end of the uncertainty interval around the value chosen in the baseline model. The parameter values that were changed are shown in Table 6.

The uncertainty regarding the initial concentration on carcasses $\left(C_{\text {initial }}\right)$ was evaluated by changing the mean or standard deviation with $+/-0.5 \log _{10}$ (U1-U4). For the prevalence $\left(P_{\text {initial }}\right)$, the upper (U5) and lower limit (U6) of the $95 \%$ confidence interval for the prevalence at the sternal region were used (Van Damme et al. 2015). A different value for the reduction during blast chilling $\left(I_{c c}\right)$ was based on the $7 \%$ cell inactivation that was observed by El-Zawahry and Grecz (1981) when freezing pathogenic $Y$. enterocolitica in broth at $-18^{\circ} \mathrm{C}$ for one hour (U7). A larger reduction during blast chilling (U8) was simulated using the -0.8 log reduction of $Y$. enterocolitica that was observed by King et al. (2012) when applying a water wash before freezing pig organs. Scenario U9 assumed no growth of pathogenic $Y$. enterocolitica during carcass cold storage, which was based on the results of Greer and Dilts (1995), who found no growth of pathogenic $Y$. enterocolitica $0: 4,32$ during storage at $4{ }^{\circ} \mathrm{C}$ for over ten days after artificial inoculation of lean pork tissue. As Greer and Dilts (1995) observed immediate growth of $Y$. enterocolitica $0: 4,32$ on pork fat at $4^{\circ} \mathrm{C}$, a lag phase of 0 hours was assumed in scenario U10. The doubling time in scenario U10 was based on ComBase results assuming a temperature of $4^{\circ} \mathrm{C}, \mathrm{pH}$ of 6.5 (Greer and Dilts, 1995), and $A_{w}$ of 0.990 (van Netten et al., 1997). The percentage of pathogenic $Y$. enterocolitica that remain on a belly cut after derinding was set at $25 \%$ and $75 \%$ to represent less and more removal during cutting and removal (U11 and U12). The lower and upper limits of the uncertainty about the weight of a batch of minced meat $\left(\mathrm{W}_{\mathrm{b}}\right)$, the proportion of bellies that is used (\%bellies), the weight of a belly cut $\left(\mathrm{W}_{\mathrm{bdr}}\right)$, the temperature $\left(\mathrm{Temp}_{\mathrm{rg}}\right)$ and the time during storage at retail (Time ${ }_{\mathrm{rg}}$ ) were considered reasonable by the authors (U13-U22). The uncertainty regarding the growth of pathogenic $Y$. enterocolitica in minced meat was studied by reducing the maximum growth rate by half (U23).

\section{Results}

Using the baseline scenario, the prevalence of pathogenic $Y$. enterocolitica in $0.5-\mathrm{kg}$ minced meat packages was estimated at $15.4 \%$ ( $\geq 1 \mathrm{CFU} /$ package). Only a small percentage of packages (1.4\%, i.e. $9.2 \%$ of the contaminated packages) contained more than $10^{3}$ pathogenic $Y$. enterocolitica at the end 
of storage. The distribution of pathogenic $Y$. enterocolitica in positive minced meat packages at the end of storage (just before consumption or preparation) in the baseline scenario is shown in Figure 2 .

\subsection{Initial contamination of carcasses before chilling}

The effect of initial carcass contamination on pathogenic $Y$. enterocolitica contaminated minced meat packages was evaluated varying the initial prevalence and concentration of pathogenic $Y$. enterocolitica on carcasses ( $P_{\text {initial }}$ and $\left.C_{\text {initial }}\right)$ to represent minced meat that is produced using carcasses from slaughterhouses with either low or high contamination with pathogenic $Y$. enterocolitica. Lowering the prevalence of pathogenic $Y$. enterocolitica on carcasses from $16.39 \%$ to 7.5\% reduced the proportion of highly contaminated meat packages by half (Figure 3). A similar reduction was seen when the average initial concentration on pork carcasses is reduced by $0.5 \log _{10}$ $\mathrm{CFU} / \mathrm{cm}^{2}$. The combined effect of reducing the prevalence and the concentration resulted in the highest effect, with a more than 5 -fold decrease in the number of highly contaminated packages before consumption. A similar but opposite effect was seen for a higher prevalence and/or higher concentration (Figure 3).

\subsection{Effect of decontamination}

The results of different scenarios to evaluate the effect of decontamination methods for carcasses at slaughterhouse level are shown in Figure 4. The use of solely conventional chilling resulted in twice as many pathogenic $Y$. enterocolitica contaminated minced meat packages compared to when it's combined with blast chilling, during which the carcass surface is frozen. Steam condensation had a larger effect on the final outcome estimates as it would reduce the number of contaminated and highly contaminated pathogenic $Y$. enterocolitica packages 95 to 158 times. The use of $2 \%$ lactic acid sprays would also reduce the proportion of pathogenic $Y$. enterocolitica contaminated minced meat packages, resulting in a larger effect in combination with blast chilling than with conventional air chilling. Using carcasses that are chilled for $68 \mathrm{~h}$ resulted in more than 10 times as many pathogenic $Y$. enterocolitica contaminated $0.5-\mathrm{kg}$ minced packages compared to minced meat that is produced using 20h-chilled carcasses (Figure 4).

\subsection{Addition of head meat and tonsillar tissue}

The additional use of $1 \%$ to $50 \%$ head meat for the production of minced meat increased the proportion of pathogenic $Y$. enterocolitica positive minced meat packages 2 to 6 times compared to the baseline scenario that only assumed pork bellies as a source of pathogenic $Y$. enterocolitica contamination (Figure 5). The impact of adding head meat was larger for highly contaminated packages than for the prevalence of pathogenic $Y$. enterocolitica positive minced meat packages. The 
321

322

323

324

325

326

327

328

329

330

331

332

333

334

335

336

337

338

339

340

341

342

343

344

345

346

347

348

349

350

351

use of $10 \%$ head meat in minced meat resulted in almost 20 times as many highly contaminated minced meat packages at time of consumption (Figure 5).

The addition of $1 \mathrm{~g}$ tonsillar tissue to a 900-kg minced meat batch resulted in a 7-fold increase of the number of minced meat packages containing $>3 \log$ pathogenic $Y$. enterocolitica at time of consumption (Figure 5 and Figure 2). The addition of one tonsil of $10 \mathrm{~g}$ resulted in a similar but slightly higher increase. The addition of 1-g tonsil pieces of 10 different pigs resulted in over 35 times as many highly contaminated minced meat packages at time of consumption (Figure 5).

Changing the batch size $\left(W_{b}\right)$ from $900 \mathrm{~kg}$ to $140 \mathrm{~kg}$ or $1500 \mathrm{~kg}$ had very little effect on the endpoint estimates (data not shown).

\subsection{Consumer storage}

When storage of minced meat at consumer level would always be at $4^{\circ} \mathrm{C}$, the proportion of highly contaminated packages would be reduced with more than a 1000-fold compared to the baseline scenario (Figure 6). If minced meat would always be consumed or prepared within one day after purchase, a reduction of the endpoint estimate was observed, whereas a constant storage time of two or more days increased the proportion of highly contaminated packages compared to the baseline scenario. For each of the scenarios, storage at ambient atmosphere resulted in a higher proportion of highly contaminated packages than storage in MAP (Figure 6). Storage of minced meat until the use-by date was simulated using a storage time at consumer level of 7 days or storage at retail for 9 days (to simulate purchase and consumption at the end of shelf life). Both scenarios estimated that nearly all pathogenic $Y$. enterocolitica positive packages after packaging (15\%) would contain $>10^{3}$ pathogenic $Y$. enterocolitica at the end of the 9-day storage period. The endpoint estimate was higher when packages were stored until the use-by date in MAP, as compared to storage at ambient atmosphere for two days or less (Figure 6).

\subsection{Uncertainty}

The results for the uncertainty analyses are shown in Figure 7. A reduced growth rate during storage at retail and consumer level had the highest impact on the proportion of highly contaminated minced meat packages. Uncertainty regarding the standard deviation of pathogenic $Y$. enterocolitica numbers on carcasses before chilling $\left(C_{\text {initial }}\right)$, reduction during blast chilling, and growth during carcass cold storage had a large effect on both endpoint estimates. For all variables that were evaluated, the uncertainty had a larger effect on the proportion of highly contaminated packages than on the prevalence of pathogenic $Y$. enterocolitica in minced meat packages. The uncertainty 
during minced meat production regarding the exact weight of a minced meat batch, the proportion of bellies and the weight of a pork belly had only a minor effect on the endpoint estimates.

\section{Discussion}

\subsection{Modelling approach}

The consumption of raw minced pork has been shown to be the main risk factor for yersiniosis infections in Germany (Rosner et al., 2012) and the knowledge of consumers regarding the correct handling of raw minced meat seems to be limited (Bremer et al., 2005). Therefore, the effect of different control measures during the production of minced meat on pathogenic $Y$. enterocolitica contaminated and highly contaminated minced meat packages were evaluated in this study. The modelling approach used was based on the Modular Process Risk Model approach (Nauta, 2008) that has frequently been applied to model the transmission of microbial pathogens through food chains for quantitative microbiological risk assessment (e.g. Nauta et al., 2007; Daelman et al., 2013; Møller et al., 2015). A full risk assessment, ending at an estimation of the risk of illness, was not feasible as only few reports are available estimating the numbers of Yersinia spp. in food products that are related to yersiniosis cases (Pärn et al., 2015; Todd et al., 2008) and, to our knowledge, no doseresponse model is available for pathogenic $Y$. enterocolitica. Moreover, due to a lack on consumption data of raw minced pork and uncertainty about preparation styles, it was decided to end the analysis at the end of storage, just before consumption of raw minced pork or preparation. Using a similar approach as Nauta et al. (2003), and acknowledging that all microbial dose response models show an increasing probability of illness with an increasing dose, it was assumed that every contaminated package may pose a health risk and that the risk of yersiniosis is higher for highly contaminated packages. The choice of the critical level $10^{3}$ was arbitrary, balancing the need for a high level with the need for a level that occurs regularly, as to get robust results with a feasible number of model iterations. When comparing two scenarios, it is assumed that the relative proportion of highly contaminated packages can be considered a reasonable surrogate for the relative risk as applied elsewhere (e.g. Møller et al., 2015).

\subsection{Uncertainties of the model and relevant data gaps}

The present model used pathogenic $Y$. enterocolitica numbers that are found on the sternal region of carcasses as input variables to represent contamination of the belly area, and assumed that pork bellies were the sole source of contamination of minced meat. Laukkanen-Ninios et al. (2014b) quantified plasmid-carrying Yersinia in meat cuts in Finland that were intended to be used in minced meat and found Yersinia in 39\% of pork cuts, varying between 0.1 and $1.6 \mathrm{MPN} / \mathrm{g}$ (average 0.41 MPN/g) using nested PCR. Nevertheless, as pathogenic $Y$. enterocolitica were isolated from one pork 
cut only (0.6\%) (Laukkanen-Ninios et al., 2014b), the contamination level of meat cuts for the production of minced meat seems very low. Nevertheless, since contamination from shoulder cuts and cross contamination between belly cuts were not included in the present model, the contamination of meat cuts with pathogenic $Y$. enterocolitica before grinding is probably underestimated. Moreover, the uncertainty analysis showed that the standard deviation of the initial concentration on carcasses had a large effect on the final prevalence of contaminated packages and especially for the proportion of highly contaminated packages. This importance of the standard deviation of concentrations has been found previously (Duarte et al., 2016). Clearly, more accurate estimations on the numbers of pathogenic $Y$. enterocolitica on bellies and other pork cuts that are used for minced meat production, including the variation between carcasses and slaughterhouses, could improve the estimations of the model.

The level of growth and inactivation of $Y$. enterocolitica has been shown to differ according to the tissue. As such, Greer and Dilts (1995) observed immediate growth of pathogenic Y. enterocolitica at $4^{\circ} \mathrm{C}$ after artificial inoculation of fat tissue whereas no growth was observed on lean tissue for several days after inoculation. The authors also found that pathogenic $Y$. enterocolitica on lean tissue were more resistant to lactic acid than those on fat tissue (Greer and Dilts, 1995). Moreover, larger reductions of $Y$. enterocolitica have been observed on pig skin compared to muscle tissue when evaluating steam-ultrasound decontamination (Morild et al., 2011) or water spraying followed by steam decontamination (Smulders et al., 2012). Nevertheless, the effect of lactic acid treatment has been shown to vary between studies. As such, van Netten et al. (1997) found a 4.7 log immediate death of $Y$. enterocolitica serotype 0:3 on pork skin after dipping in $2 \%$ lactic acid at $37^{\circ} \mathrm{C}$ for $120 \mathrm{~s}$. Such reductions would reduce the proportion of highly contaminated packages with more than a 1000 -fold (data not shown), though this is likely an overestimation of the reduction as such conditions may not be accomplished under field conditions. Besides the immediate effect of lactic acid, the present model assumed a reduced growth of $Y$. enterocolitica during carcass cold storage after the application of $2 \%$ lactic acid, which are based on data using pork skin (van Netten et al., 1997). Nevertheless, Greer and Dilts (1995) observed a persistent reduction of $Y$. enterocolitica in the next seven days following a $3 \%$ lactic acid treatment of pig lean and fat tissue stored at $4^{\circ} \mathrm{C}$. Therefore, studies quantifying the immediate and long-term effect of lactic acid on carcasses under field conditions are necessary to improve the predictions for lactic acid decontamination. As the attachment, inactivation, and growth of pathogenic $Y$. enterocolitica may differ according to the surface type (Greer and Dilts, 1995; Morild et al., 2011), the inclusion of these differences would be a more realistic approach to model $Y$. enterocolitica on carcasses, but this would considerably increase the complexity of the model. Moreover, this would require comprehensive data on the distribution, 
growth and inactivation of the pathogens on each of the different tissues on carcasses, which are currently not available. Nevertheless, as the level of growth and inactivation of $Y$. enterocolitica during cold storage may have a large influence on the outcome variables, more accurate studies on the level of reduction of pathogenic $Y$. enterocolitica on carcasses under different chilling and cold storage conditions - including the biological and strain variation - should be performed to obtain more accurate endpoint estimates.

Data regarding the growth of pathogenic $Y$. enterocolitica on pork, and minced meat in particular, are limited. Therefore, the growth rate represented a large uncertainty in the present model. Kleinlein and Untermann (1990) observed growth of pathogenic Y. enterocolitica in minced beef stored in $\operatorname{MAP}\left(20 \% \mathrm{CO}_{2}, 80 \% \mathrm{O}_{2}\right)$, especially at temperatures of $10^{\circ} \mathrm{C}$ or higher, whereas Strotmann et al. (2008) observed a reduction of $Y$. enterocolitica bioserotype 4/O:3 during storage at $2^{\circ} \mathrm{C}$, regardless of the $\mathrm{CO}_{2}$ concentration. After 13 days of storage of pig cheeks at $6^{\circ} \mathrm{C}$ in $30 \% \mathrm{CO}_{2}$ and $70 \% \mathrm{O}_{2}$, Fredriksson-Ahomaa et al. (2012) observed $Y$. enterocolitica bioserotype 4/0:3 in numbers varying between 2.3 and $5.4 \log$ CFU/g. Due to the different factors affecting growth and the large impact it has on prevalence and concentrations found in packages after consumer storage, more studies are needed regarding the growth of the pathogen in minced meat at different temperatures, including the variation between strains and varying meat characteristics.

\subsection{Interventions to control pathogenic $Y$. enterocolitica}

The prevalence of pathogenic $Y$. enterocolitica on carcasses was set at $16.4 \%$ for the baseline model, though the proportion of carcasses that are pathogenic $Y$. enterocolitica positive at the sternal region have been shown to vary between slaughterhouses from 7.5 to 37.5\% (Van Damme et al., 2015). Comparing minced meat that is produced from carcasses originating from "good" slaughterhouses (that produce carcasses with a low prevalence and low concentration) compared to "bad" slaughterhouses (that produce carcasses with a high prevalence and a high concentration), results in a more than 30 -fold increase in the proportion of highly contaminated $Y$. enterocolitica minced meat packages. This finding demonstrates the utility of risk differentiation of slaughterhouses (EFSA, 2011) to control pathogenic $Y$. enterocolitica transmission via minced meat. As the combined effect of reducing the prevalence and concentration of pathogenic $Y$. enterocolitica on carcasses resulted in the greatest reduction of highly contaminated minced meat packages, measures to decrease both the number of positive carcasses and the concentration of pathogenic $Y$. enterocolitica on carcasses would result in the largest benefit. Many different physical and chemical decontamination treatments have been described to reduce bacterial contamination on pig carcasses (Loretz et al., 2011). Besides the effect of (blast) chilling as the most conventional way to reduce bacterial contamination on carcasses, the effect of steam decontamination and lactic acid decontamination 
were simulated to represent commonly used physical and chemical decontamination procedures of pig carcasses. Although blast chilling before conventional chilling has been shown to result in a larger reduction than conventional air chilling alone for different pathogens (Loretz et al., 2011), blast chilling has been shown not to reduce pathogenic $Y$. enterocolitica recovery from carcasses (Nesbakken et al., 2008). The effect of blast chilling on the outcome estimate also seemed rather limited in the present model. The use of decontamination procedures on carcasses before chilling was estimated to result in higher reductions of the proportion of highly contaminated minced meat packages, and would thus likely reduce the public health risk.

The baseline model assumed pork bellies as the only source of pathogenic $Y$. enterocolitica contamination during the production of minced meat. Meat cuts originating from other parts of the carcass may be contaminated in higher levels and numbers, which would increase the numbers of pathogenic $Y$. enterocolitica in a minced meat batch and the resulting minced meat packages. Pork cheeks and tongues have been shown to be highly contaminated with pathogenic $Y$. enterocolitica (Laukkanen-Ninios et al., 2014b; Messelhausser et al., 2011). As such, the addition of different levels of head meat for the production of minced meat was simulated using qualitative and quantitative data from the mandibular region on pig carcasses before cooling as input data to represent meat from pork cheeks and the throat region. The use of head meat for the production of minced meat increased the proportion of pathogenic $Y$. enterocolitica positive minced meat packages with increasing amounts of head meat and had a larger effect on highly contaminated minced meat packages. The addition of just $10 \%$ head meat in minced meat resulted in almost 20 as many highly contaminated minced meat packages at time of consumption. The addition of pork cheeks and other potentially highly contaminated meat cuts (such as throat meat) should thus be avoided for the production of minced meat that is potentially consumed raw.

Tonsils have been shown to be highly contaminated with human pathogenic Yersinia spp. (Bonardi et al., 2016; Van Damme et al., 2010) and represent an important risk for carcass contamination. Tonsils should be removed hygienically after post mortem inspection according to EU regulation (EC) No. $853 / 2004$, though parts may remain in the head and result in contamination further down the pork production line (Fredriksson-Ahomaa et al., 2004). The addition of minimal amounts of tonsillar tissue in minced meat resulted in a large effect in the proportion of highly contaminated minced meat packages before consumption, so special care should be taken to remove all remaining tonsillar tissue from the carcass.

Minced meat produced on Monday resulted in a higher proportion of highly contaminated packages than minced meat produced on Tuesday to Friday. Industrially produced minced meat is usually 
made from carcasses that are slaughtered the previous day, though carcasses from pigs that are slaughtered on Friday are stored during the weekend for processing on Monday, resulting in a longer cold storage. After storage of pork bellies during 4 and 8 days at $4^{\circ} \mathrm{C}$, van Netten et al. (1997) observed more than 1 and $4 \log _{10}$ increase of cold and acid adapted $Y$. enterocolitica serotype 0:3. Therefore, minced meat that is produced from carcasses that have been stored for several days may represent a larger risk for public health than freshly slaughtered pig carcasses. This implies that the shelf life for minced meat may be adapted depending on the cold storage time of carcasses to reduce the proportion of minced meat packages that are (highly) contaminated with pathogenic $Y$. enterocolitica.

Consumer practices were shown to have a large effect on the proportion of minced meat packages with high numbers of pathogenic $Y$. enterocolitica at time of consumption. When all consumers would store minced meat at $4^{\circ} \mathrm{C}$, a 1000 -fold reduction in the number of highly contaminated packages could be expected. A similar reduction was seen if consumers would consume the minced meat at the day of purchase. Storage of minced meat in ambient atmosphere leads to higher maximum growth rates for $Y$. enterocolitica compared to packaging with $30 \% \mathrm{CO}_{2}$, resulting in higher estimates of highly contaminated packages at the end of storage. Nevertheless, the storage time at ambient atmosphere is presumably shorter compared to minced meat stored under MAP conditions due to the shorter shelf life (Strotmann et al., 2008). Limbo et al. (2010) calculated that the mean shelf life of MAP minced beef was 9 days at the recommended storage temperature of about $4^{\circ} \mathrm{C}$. The proportion of highly contaminated packages in the present study was higher when all MAP would be stored until the use-before date compared to the storage of packages at ambient atmosphere for two days or less. Although MAP is introduced to reduce bacterial growth and prolong shelf-life of products, the longer shelf-life could potentially increase the risk of yersiniosis due to the growth of pathogenic $Y$. enterocolitica during prolonged storage at refrigerated conditions.

\section{Conclusions}

Meat producers should focus on reducing the number of pathogenic $Y$. enterocolitica contaminated minced meat packages, which can be achieved by using meat cuts that are less contaminated with pathogenic $Y$. enterocolitica. As such, belly cuts should be preferred over head meat. Moreover, meat produced from carcasses of slaughterhouses with lower contamination results in less pathogenic $Y$. enterocolitica contaminated minced meat packages. Finally, it's important that the tonsils are completely removed in the slaughterhouse as the (accidental) addition of minimal amounts of tonsillar tissue has a large effect on the proportion of highly contaminated minced meat packages. Nevertheless, the number of packages that contain high numbers of pathogenic $Y$. enterocolitica, which are expected to cause the highest risk of yersiniosis, is primarily influenced by consumer 
storage practices. A reduced storage time (under one day) or a storage temperature (below $4^{\circ} \mathrm{C}$ ) would largely reduce the proportion of packages containing high numbers of pathogenic $Y$. enterocolitica.

This research did not receive any specific grant from funding agencies in the public, commercial, or not-for-profit sectors.

\section{References}

Bonardi, S., Bruini, I., D'Incau, M., Van Damme, I., Carniel, E., Brémont, S., Cavallini, P., Tagliabue, S., Brindani, F., 2016. Detection, seroprevalence and antimicrobial resistance of Yersinia enterocolitica and Yersinia pseudotuberculosis in pig tonsils in Northern Italy. Int. J. Food Microbiol. 235, 125-132.

Borch, E., Nesbakken, T., Christensen, H., 1996. Hazard identification in swine slaughter with respect to foodborne bacteria. Int. J. Food Microbiol. 30, 9-25.

Bremer, V., Bocter, N., Rehmet, S., Klein, G., Breuer, T., Ammon, A., 2005. Consumption, knowledge, and handling of raw meat: a representative cross-sectional survey in Germany, March 2001. J. Food Prot. 68, 785-789.

Daelman, J., Membré, J.-M., Jacxens, L., Vermeulen, A., Devlieghere, F., Uyttendaele, M., 2013. A quantitative microbiological exposure assessment model for Bacillus cereus in REPFEDs. Int. J. Food Microbiol. 166, 433-449.

Devriese, S., Huybrechts, I., Moreau, M., Van Oyen, H., 2006. De Belgische Voedselconsumptiepeiling 1 - 2004. Brussels (Belgium).

Duarte, A.S.R., Nauta, M.J., Aabo, S., 2016. Variation in the effect of carcass decontamination impacts the risk for consumers.

El-Zawahry, Y.A., Grecz, N., 1981. Inactivation and injury of Yersinia enterocolitica by radiation and freezing. Appl. Environ. Microbiol. 42, 464-468.

European Food Safety Authority (EFSA), 2011. Scientific Opinion on the public health hazards to be covered by inspection of meat (swine). EFSA J. 9(10): 2351. doi:10.2903/j.efsa.2011.2351.

European Food Safety Authority (EFSA), 2009. Technical specifications for harmonised national surveys of Yersinia enterocolitica in slaughter pigs on request of EFSA. EFSA J. 7(11):1374. doi:10.2903/j.efsa.2009.1374.

European Food Safety Authority (EFSA), European Centre for Disease Prevention and Control (ECDC), 2015. The European Union summary report on trends and sources of zoonoses, zoonotic agents and food-borne outbreaks in 2013, EFSA J. 13(1): 3991. doi:10.2903/j.efsa.2015.3991

Fosse, J., Seegers, H., Magras, C., 2008. Foodborne zoonoses due to meat: a quantitative approach for a comparative risk assessment applied to pig slaughtering in Europe. Vet. Res. 39:1. doi:10.1051/vetres:2007039

Fredriksson-Ahomaa, M., Koch, U., Klemm, C., Bucher, M., Stolle, A., 2004. Different genotypes of Yersinia enterocolitica 4/0:3 strains widely distributed in butcher shops in the Munich area. Int. J. Food Microbiol. 95, 89-94. 
Fredriksson-Ahomaa, M., Murros-Kontiainen, A., Säde, E., Puolanne, E., Björkroth, J., 2012. High number of Yersinia enterocolitica 4/0:3 in cold-stored modified atmosphere-packed pig cheek meat. Int. J. Food Microbiol. 155, 69-72.

Greer, G.G., Dilts, B.D., 1995. Lactic acid inhibition of the growth of spoilage bacteria and cold tolerant pathogens on pork. Int. J. Food Microbiol. 25, 141-151.

Havelaar, A.H., Evers, E.G., Nauta, M.J., 2008. Challenges of quantitative microbial risk assessment at EU level. Trends Food Sci. Technol. 19, S26-S33.

King, A.M., Miller, R.K., Castillo, A., Griffin, D.B., Hardin, M.D., 2012. Effects of lactic acid and commercial chilling processes on survival of Salmonella, Yersinia enterocolitica, and Campylobacter coli in pork variety meats. J. Food Prot. 75, 1589-1594.

Kleinlein, N., Untermann, F., 1990. Growth of pathogenic Yersinia enterocolitica strains in minced meat with and without protective gas with consideration of the competitive background flora. Int. J. Food Microbiol. 10, 65-71.

Laukkanen, R., Ranta, J., Dong, X., Hakkinen, M., Martinez, P.O., Lunden, J., Johansson, T., Korkeala, $\mathrm{H}$., 2010. Reduction of enteropathogenic Yersinia in the pig slaughterhouse by using bagging of the rectum. J. Food Prot. 73, 2161-2168.

Laukkanen-Ninios, R., Fredriksson-Ahomaa, M., Korkeala, H., 2014a. Enteropathogenic Yersinia in the Pork Production Chain: Challenges for Control. Compr. Rev. Food Sci. Food Saf. 13, 1165-1191.

Laukkanen-Ninios, R., Fredriksson-Ahomaa, M., Maijala, R., Korkeala, H., 2014b. High prevalence of pathogenic Yersinia enterocolitica in pig cheeks. Food Microbiol. 43, 50-52.

Limbo, S., Torri, L., Sinelli, N., Franzetti, L., Casiraghi, E., 2010. Evaluation and predictive modeling of shelf life of minced beef stored in high-oxygen modified atmosphere packaging at different temperatures. Meat Sci. 84, 129-136.

Loretz, M., Stephan, R., Zweifel, C., 2011. Antibacterial activity of decontamination treatments for pig carcasses. Food Control 22, 1121-1125.

Marklinder, I.M., Lindblad, M., Eriksson, L.M., Finnson, a M., Lindqvist, R., 2004. Home storage temperatures and consumer handling of refrigerated foods in Sweden. J. Food Prot. 67, 25702577.

Messelhausser, U., Kampf, P., Colditz, J., Bauer, H., Schreiner, H., Holler, C., Busch, U., 2011. Qualitative and quantitative detection of human pathogenic Yersinia enterocolitica in different food matrices at retail level in Bavaria. Foodborne Pathog. Dis. 8, 39-44.

Møller, C.O. de A., Nauta, M.J., Schaffner, D.W., Dalgaard, P., Christensen, B.B., Hansen, T.B., 2015. Risk assessment of Salmonella in Danish meatballs produced in the catering sector. Int. J. Food Microbiol. 196, 109-125.

Morild, R.K., Christiansen, P., Sørensen, A.H., Nonboe, U., Aabo, S., 2011. Inactivation of pathogens on pork by steam-ultrasound treatment. J. Food Prot. 74, 769-775.

Murros, A., Säde, E., Johansson, P., Korkeala, H., Fredriksson-Ahomaa, M., Björkroth, J., 2016. Characterization of European Yersinia enterocolitica $1 \mathrm{~A}$ strains using restriction fragment length polymorphism and multilocus sequence analysis. Lett. Appl. Microbiol.

Nauta, M.J., 2008. The Modular process risk model (MPRM): a structured approach to food chain exposure assessment, in: Schaffer, D.W. (Ed.), Microbial Risk Analysis of Foods. ASM Press, Washington, D.C., pp. 99-136. 
Nauta, M.J., 2005. Microbiological risk assessment models for partitioning and mixing during food handling. Int. J. Food Microbiol. 100, 311-322.

Nauta, M.J., Jacobs-Reitsma, W.F., Havelaar, A.H., 2007. A Risk Assessment Model for Campylobacter in Broiler Meat. Risk Anal. 27, 845-861.

Nauta, M.J., Litman, S., Barker, G.C., Carlin, F., 2003. A retail and consumer phase model for exposure assessment of Bacillus cereus. Int. J. Food Microbiol. 83, 205-218.

Nesbakken, T., Eckner, K., Røtterud, O.J., 2008. The effect of blast chilling on occurrence of human pathogenic Yersinia enterocolitica compared to Campylobacter spp. and numbers of hygienic indicators on pig carcasses. Int. J. Food Microbiol. 123, 130-133.

OECD, 2016. Meat consumption (indicator). OECD-FAO Agricultural Outlook. doi:10.1787/fa290fd0en

Pärn, T., Hallanvuo, S., Salmenlinna, S., Pihlajasaari, A., Heikkinen, S., Telkki-Nykänen, H., Hakkinen, M., Ollgren, J., Huusko, S., Rimhanen-Finne, R., 2015. Outbreak of Yersinia pseudotuberculosis O:1 infection associated with raw milk consumption, Finland, spring 2014. Euro Surveill. 20, 30033.

Pouillot, R., Delignette-Muller, M.L., 2010. Evaluating variability and uncertainty separately in microbial quantitative risk assessment using two R packages. Int. J. Food Microbiol. 142, 330340.

Rosner, B.M., Stark, K., Höhle, M., Werber, D., 2012. Risk factors for sporadic Yersinia enterocolitica infections, Germany 2009-2010. Epidemiol. Infect. 140, 1738-1747.

Schneeberger, M., Brodard, I., Overesch, G., 2015. Virulence-associated gene pattern of porcine and human Yersinia enterocolitica biotype 4 isolates. Int. J. Food Microbiol.

Smulders, F.J.M., Wellm, G., Hiesberger, J., Bauer, A., Paulsen, P., 2012. The potential of the combined application of hot water sprays and steam condensation at subatmospheric pressure for decontaminating inoculated pig skin and muscle surfaces. Food Control 24, 154-159.

Strotmann, C., von Mueffling, T., Klein, G., Nowak, B., 2008. Effect of different concentrations of carbon dioxide and oxygen on the growth of pathogenic Yersinia enterocolitica 4/0:3 in ground pork packaged under modified atmospheres. J. Food Prot. 71, 845-849.

Todd, E.C.D., Greig, J.D., Bartleson, C.A., Michaels, B.S., 2008. Outbreaks where food workers have been implicated in the spread of foodborne disease. Part 4. Infective Doses and Pathogen Carriage. J. Food Prot. 71, 2339-2373.

Van Damme, I., Berkvens, D., Vanantwerpen, G., Baré, J., Houf, K., Wauters, G., De Zutter, L., 2015. Contamination of freshly slaughtered pig carcasses with enteropathogenic Yersinia spp.: Distribution, quantification and identification of risk factors. Int. J. Food Microbiol. 204, 33-40.

Van Damme, I., Habib, I., De Zutter, L., 2010. Yersinia enterocolitica in slaughter pig tonsils: Enumeration and detection by enrichment versus direct plating culture. Food Microbiol. 27, 158-161.

van Netten, P., Valentijn, A., Mossel, D.A., Huis in 't Veld, J.H., 1997. Fate of low temperature and acid-adapted Yersinia enterocolitica and Listeria monocytogenes that contaminate lactic acid decontaminated meat during chill storage. J. Appl. Microbiol. 82, 769-779.

Vilar, M.J., Virtanen, S., Laukkanen-Ninios, R., Korkeala, H., 2015. Bayesian modelling to identify the risk factors for Yersinia enterocolitica contamination of pork carcasses and pluck sets in slaughterhouses. Int. J. Food Microbiol. 197, 53-57. 
Figure captations

Figure 1. Food pathway of the baseline model to describe $Y$. enterocolitica in minced meat produced by an industrial meat processing plant.

The model starts with the contamination of carcasses in the slaughterhouse after evisceration and ends with a 0.5-package of minced pork just before consumption and/or preparation.

Figure 2. Distributions of concentrations of $Y$. enterocolitica in $0.5-\mathrm{kg}$ minced meat packages after storage at consumer level (based on 100000 iterations) using (1) the baseline scenario that only assumed pork bellies as a source of contamination (dashed line) and (2) the alternative scenario in which $1 \mathrm{~g}$ of tonsillar tissue is added to a 900-kg minced batch (solid line).

Concentrations of $Y$. enterocolitica are given for contaminated packages only; the areas under the curves reflect the prevalence of $15.4 \%$ in the baseline scenario and $37.9 \%$ in the alternative scenario.

Figure 3. Effect of initial pig carcass contamination in slaughterhouses on Y. enterocolitica contamination of minced meat packages just before consumption.

The proportion of $Y$. enterocolitica positive minced meat packages of the alternative scenarios are expressed relative to the proportion of minced meat packages in the baseline model. Relative proportions are log transformed, so the baseline gets a value zero, and -1 and 1 represent a tenfold reduction and increase of the proportion, respectively. The baseline model used a prevalence $\left(P_{\text {initial }}\right)$ of $16.4 \%$ and a mean concentration $\left(C_{\text {initial }}\right)$ of $-2.565 \log _{10} Y$. enterocolitica $/ \mathrm{cm}^{2}$. Alternative scenarios were simulated using a lower/higher prevalence $\left(\mathrm{P}_{\text {initial }}\right.$ of $7.5 \%$ or $37.5 \%$, respectively) and/or a lower/higher concentration (mean $C_{\text {initial }}$ of $0.5 \log _{10}$ lower or higher compared to the baseline value, respectively). The grey bars represent the outcome of the proportion of $Y$. enterocolitica positive 0.5$\mathrm{kg}$ minced meat packages. The black bars represent the results for $0.5-\mathrm{kg}$ minced meat packages that contain more than $3 \log _{10} Y$. enterocolitica at time of consumption or preparation.

Figure 4. Effect of cooling and carcass decontamination steps on $Y$. enterocolitica contaminated minced meat packages.

The proportion of $Y$. enterocolitica positive minced meat packages of the alternative scenarios are expressed relative to the proportion of minced meat packages in the baseline model. The baseline model assumed a $0.6 \mathrm{log}$ reduction of $Y$. enterocolitica during blast chilling. The storage time of carcasses in the baseline model was $20 \mathrm{~h}$ (for carcasses of pigs slaughtered on Monday-Thursday) or $68 \mathrm{~h}$ (for carcasses of pigs slaughtered on Friday).

The grey bars represent the outcome of the proportion of $Y$. enterocolitica positive 0.5-kg minced meat packages. The black bars represent the proportion of $0.5-\mathrm{kg}$ minced meat packages that contain more than $3 \log _{10} Y$. enterocolitica at time of consumption or preparation. 
677 Figure 5. Evaluation of the addition of head meat and tonsillar tissue to a 900-kg batch of minced 678 meat on $Y$. enterocolitica contaminated minced meat packages just before consumption.

679 The proportion of $Y$. enterocolitica positive minced meat packages of the alternative scenarios are 680 expressed relative to the proportion of minced meat packages in the baseline model. The baseline 681 model only assumed pork bellies as a source of $Y$. enterocolitica contamination. The grey bars 682 represent the outcome of the proportion of $Y$. enterocolitica positive $0.5-\mathrm{kg}$ minced meat packages.

683 The black bars represent the proportion of $0.5-\mathrm{kg}$ minced meat packages that contain more than 3

$684 \log _{10} Y$. enterocolitica at time of consumption or preparation.

\section{Figure 6. Evaluation of consumer practices on $Y$. enterocolitica contaminated minced meat}

686 packages just before consumption.

687 The proportion of highly contaminated $\left(>3 \log _{10}\right)$ Y. enterocolitica $0.5-\mathrm{kg}$ minced meat packages of

688 the alternative scenarios are expressed relative to the proportion of highly contaminated $0.5-\mathrm{kg}$

689 minced meat packages in the baseline model (= stored in modified atmosphere packages (MAP), 30\%

$690 \mathrm{CO}_{2}$ ). The black bars represent minced meat packages stored in MAP. The bars with diagonal stripes

691 represent storage at ambient atmosphere. * Storage until use-by date was only simulated for MAP

692 minced meat.

693 Figure 7. Results of the uncertainty analyses of the baseline model.

694 The grey bars represent the outcome of the proportion of $Y$. enterocolitica positive 0.5-kg minced 695 meat packages. The black bars represent the proportion of $0.5-\mathrm{kg}$ minced meat packages that 696 contain more than $3 \log _{10} Y$. enterocolitica at time of consumption or preparation. The relative 697 proportion for U23 (reduced growth in minced meat) was truncated at -1.5. 


\section{ACCEPTED MANUSCRIPT}

Table 1. Overview of the different steps, processes and units that were used in the risk assessment model for $Y$. enterocolitica in minced pork.

\begin{tabular}{|c|c|c|c|}
\hline \multicolumn{2}{|c|}{ Processing step } & Basic process & Unit \\
\hline 1 & $\begin{array}{l}\text { Contamination of carcasses (after } \\
\text { evisceration, before chilling) }\end{array}$ & $\begin{array}{l}\text { Initial } \\
\text { contamination }\end{array}$ & Carcass half - belly area $\left(2000 \mathrm{~cm}^{2}\right)$ \\
\hline 2 & Chilling room & $\begin{array}{l}\text { Inactivation } \\
\text { Growth }\end{array}$ & Carcass half - belly area $\left(2000 \mathrm{~cm}^{2}\right)$ \\
\hline 3 & Cutting and derinding & Removal & Belly cut $\left(2000 \mathrm{~cm}^{2} ; 7.5 \mathrm{~kg}\right)$ \\
\hline 4 & Grinding and seasoning & Mixing & Batch of minced meat $(900 \mathrm{~kg})$ \\
\hline 5 & Packaging & Partitioning & Minced meat package $(0.5 \mathrm{~kg})$ \\
\hline 6 & $\begin{array}{l}\text { Storage (meat processing plant and } \\
\text { retail) }\end{array}$ & Growth & Minced meat package (0.5 kg) \\
\hline & Storage (consumer) & Growth & Minced meat package $(0.5 \mathrm{~kg})$ \\
\hline
\end{tabular}


Table 2. Overview of variables and parameters in the baseline Modular Process Risk Model (MPRM) for human pathogenic $Y$. enterocolitica in minced meat.

\begin{tabular}{|c|c|c|c|c|c|}
\hline Module & Variable & Description & Unit & Value/distribution/equation & Source \\
\hline \multirow[t]{2}{*}{$\begin{array}{l}\text { Input (carcasses, } \\
\text { sternal region, after } \\
\text { evisceration) }\end{array}$} & $\mathrm{P}_{\text {initial }}$ & $\begin{array}{l}\text { Prevalence of } Y \text {. enterocolitica on pig } \\
\text { carcasses (sternal region) after } \\
\text { evisceration }\end{array}$ & $\%$ & 16.39 & $\begin{array}{l}\text { Van Damme et al. } \\
\text { (2015) }\end{array}$ \\
\hline & $\mathrm{C}_{\text {initial }}$ & $\begin{array}{l}\text { Concentration of } Y \text {. enterocolitica on } \\
\text { pig carcasses (sternal region) after } \\
\text { evisceration (positive carcasses only) }\end{array}$ & $\begin{array}{l}\log _{10} \\
\mathrm{CFU} / \mathrm{cm}^{2}\end{array}$ & $\begin{array}{l}\sim \text { Normal }(-2.565 ; 0.736) \text { truncated at a } \\
\text { minimum value of }-1.85\end{array}$ & $\begin{array}{l}\text { Calculated based on } \\
\text { data from Van Damme } \\
\text { et al. (2015) }\end{array}$ \\
\hline \multirow[t]{2}{*}{$\begin{array}{l}\text { Inactivation during } \\
\text { carcass chilling }\end{array}$} & $\mathrm{I}_{\mathrm{cc}}$ & Inactivation & $\begin{array}{l}\log _{10} \\
\text { reduction }\end{array}$ & $-0.6=$ & King et al. (2012) \\
\hline & $\mathrm{C}_{\mathrm{cci}}$ & $\begin{array}{l}\text { Concentration on pig carcasses after } \\
\text { inactivation during chilling }\end{array}$ & $\begin{array}{l}\log _{10} \\
\mathrm{CFU} / \mathrm{cm}^{2}\end{array}$ & $=\mathrm{C}_{\text {initial }}+\mathrm{I}_{\mathrm{cc}}$ & Calculation \\
\hline \multirow[t]{4}{*}{$\begin{array}{l}\text { Growth during carcass } \\
\text { cold storage }\end{array}$} & Time $_{\text {ccg }}$ & $\begin{array}{l}\text { Cold storage time of carcasses and all } \\
\text { head meat and tonsils applied in the } \\
\text { same batch }\end{array}$ & $\mathrm{h}$ & $\sim$ Discrete $(20,68),(4,1)$ & Company info \\
\hline & $\lambda_{\text {ccg }}$ & Lag phase during carcass cold storage & $\mathrm{h} \quad \mathrm{y}$ & 24 & Van Netten et al. (1997) \\
\hline & $\mathrm{D}_{\mathrm{ccg}}$ & Doubling time during cold storage & $\mathrm{h}$ & 9.978 & ComBase \\
\hline & $\mathrm{N}_{\mathrm{ccg}}$ & $\begin{array}{l}\text { Number of } Y \text {. enterocolitica after } \\
\text { growth during cold storage }\end{array}$ & $\mathrm{CFU} / \mathrm{cm}^{2}$ & $=10^{\mathrm{Ccci}} \times 2^{\left(\mathrm{Time}_{\mathrm{ccg}}-\lambda_{\mathrm{ccg}}\right) / \mathrm{D}_{\mathrm{ccg}}}$ & Calculation \\
\hline \multirow[t]{4}{*}{ Cutting and derinding } & $\mathrm{S}_{\mathrm{bc}}$ & Surface of belly cut & $\mathrm{cm}^{2}$ & 2000 & Assumption \\
\hline & $\mathrm{N}_{\mathrm{bc}}$ & $\begin{array}{l}\text { Number of } Y \text {. enterocolitica per belly } \\
\text { after cutting }\end{array}$ & CFU/belly & $=\mathrm{N}_{\mathrm{ccg}} \times \mathrm{S}_{\mathrm{bc}}($ rounded to an integer value $)$ & Calculation \\
\hline & $\mathrm{R}_{\mathrm{bd}}$ & $\begin{array}{l}\text { Proportion of } Y \text {. enterocolitica that } \\
\text { remain on the belly cut after } \\
\text { derinding }\end{array}$ & $\%$ & $50 \%$ & Assumption \\
\hline & $\mathrm{N}_{\mathrm{bdr}}$ & $\begin{array}{l}\text { Number of } Y \text {. enterocolitica on belly } \\
\text { cut after derinding }\end{array}$ & CFU/belly & $\sim \operatorname{Binomial}\left(\mathrm{N}_{\mathrm{bc}}, \mathrm{R}_{\mathrm{bd}}\right)$ & Calculation \\
\hline \multirow[t]{5}{*}{ Mixing and grounding } & $\mathrm{W}_{\mathrm{b}}$ & Weight of a batch of minced meat & $\mathrm{kg}$ & 900 & Company information \\
\hline & \%bellies & Proportion of bellies per batch (w:w) & $\%$ & 34 & Company information \\
\hline & $\mathrm{W}_{\mathrm{bc}}$ & Weight of a belly cut & $\mathrm{kg}$ & 7.5 & Company information \\
\hline & $\mathrm{n}_{\mathrm{bb}}$ & Number of bellies per batch & & $=\frac{\mathrm{W}_{\mathrm{b}} \times \% \text { bellies }}{\mathrm{W}_{\mathrm{bc}}}$ & Calculation \\
\hline & $\mathrm{n}_{\mathrm{pbb}}$ & Number of positive bellies per batch & & $\sim \operatorname{Binomial}\left(\mathrm{n}_{\mathrm{bb}}, \mathrm{P}_{\text {initial }}\right)$ & Calculation \\
\hline
\end{tabular}




\begin{tabular}{|c|c|c|c|c|c|}
\hline & $\mathrm{N}_{\mathrm{mb}}$ & $\begin{array}{l}\text { Number of } Y \text {. enterocolitica in one } \\
\text { minced meat batch }\end{array}$ & $\mathrm{CFU}$ & $=\sum_{i=1}^{\mathrm{n}_{\mathrm{pbb}}} \mathrm{N}_{\mathrm{bdr}, \mathrm{i}}$ & Calculation \\
\hline \multirow[t]{2}{*}{ Partitioning/packaging } & $\mathrm{W}_{\mathrm{mp}}$ & Weight per minced meat package & $\mathrm{kg}$ & 0.5 & Company information \\
\hline & $\mathrm{N}_{\mathrm{mp}}$ & $\begin{array}{l}\text { Number of } Y \text {. enterocolitica in one } \\
\text { minced meat package after } \\
\text { packaging/partitioning }\end{array}$ & CFU & $\sim \operatorname{Binomial}\left(\mathrm{N}_{\mathrm{mb}}, \mathrm{W}_{\mathrm{mp}} / \mathrm{W}_{\mathrm{b}}\right)$ & Assumption \\
\hline \multirow[t]{4}{*}{ Storage at retail } & Temp $_{\text {rg }}$ & $\begin{array}{l}\text { Temperature during storage in meat } \\
\text { processing plant and at retail }\end{array}$ & ${ }^{\circ} \mathrm{C}$ & 4 & Assumption \\
\hline & Time $_{\text {rg }}$ & $\begin{array}{l}\text { Time between packaging and selling } \\
\text { at retail }\end{array}$ & $\mathrm{h}$ & 48 & Assumption \\
\hline & $\mu_{\max , \mathrm{rg}}$ & Maximum growth rate (MAP) & $\begin{array}{l}\log _{10} \\
\mathrm{CFU} / \mathrm{h}\end{array}$ & $\begin{array}{l}=0.0003 \times \mathrm{Temp}_{\mathrm{rg}}{ }^{2}+0.0005 \times \mathrm{Temp}_{\mathrm{rg}}+ \\
0.0103\end{array}$ & ComBase \\
\hline & $\mathrm{N}_{\mathrm{rg}}$ & $\begin{array}{l}\text { Number of } Y \text {. enterocolitica in one } \\
\text { package of minced meat after storage } \\
\text { at retail }\end{array}$ & CFU & $=\mathrm{N}_{\mathrm{mp}} \times 10^{\mu_{\mathrm{max}, \mathrm{rg}} \times \mathrm{Time}_{\mathrm{rg}}}$ & Calculation \\
\hline \multirow{4}{*}{$\begin{array}{l}\text { Storage at consumer } \\
\text { level }\end{array}$} & Temp $_{\mathrm{cg}}$ & Temperature of home refrigerators & ${ }^{\circ} \mathrm{C}$ & $\sim \operatorname{Pert}(25 \%$ 5; 50\% 7; 75\% 9) & Devriese et al. (2006) \\
\hline & Time $_{\mathrm{cg}}$ & $\begin{array}{l}\text { Time between purchase and } \\
\text { consumption/preparation }\end{array}$ & days & $\sim \operatorname{Pert}(0 ; 1 ; 4)$ & Marklinder et al. (2004) \\
\hline & $\mu_{\text {max,cg }}$ & Maximum growth rate (MAP) & $\begin{array}{l}\log _{10} \\
\mathrm{CFU} / \mathrm{h}\end{array}$ & $\begin{array}{c}0.0003 \times \mathrm{Temp}_{\mathrm{cg}}{ }^{2}+0.0005 \times \mathrm{Temp}_{\mathrm{cg}} \\
+0.0103\end{array}$ & ComBase \\
\hline & $\mathrm{N}_{\mathrm{cg}}$ & $\begin{array}{l}\text { Number of } Y \text {. enterocolitica in one } \\
\text { package of minced meat at the end of } \\
\text { storage (just before consumption or } \\
\text { preparation) }\end{array}$ & $\begin{array}{l}\text { CFU/0.5-kg } \\
\text { package }\end{array}$ & $=\mathrm{N}_{\mathrm{rg}} \times 10^{\mu_{\mathrm{max}, \mathrm{cg}} \times \text { Time }_{\mathrm{cg}} \times 24}$ & Calculation \\
\hline
\end{tabular}


Table 3. Overview of variables and parameters to evaluate alternative scenarios at slaughterhouse level.

\begin{tabular}{|c|c|c|c|c|}
\hline Code & Description of the scenario & Variable & Alternative value/distribution/model & Source \\
\hline A1 & Lower initial prevalence on carcasses & $\mathrm{P}_{\text {initial }}$ & 7.5 & Van Damme et al. (2015) \\
\hline A2 & Lower initial concentration on carcasses & $\mathrm{C}_{\text {initial }}$ & $\begin{array}{l}\sim \text { Normal }(-3.065 ; 0.736) \text { truncated at a } \\
\text { minimum value of }-1.85\end{array}$ & $\begin{array}{l}\text { Based on data from Van } \\
\text { Damme et al. (2015) }\end{array}$ \\
\hline \multirow[t]{2}{*}{ A3 } & \multirow[t]{2}{*}{ Lower initial prevalence and concentration on carcasses } & $\mathrm{P}_{\text {initial }}$ & +2 & Van Damme et al. (2015) \\
\hline & & $\mathrm{C}_{\text {initial }}$ & $\begin{array}{l}\sim \text { Normal }(-3.065 ; 0.736) \text { truncated at a } \\
\text { minimum value of }-1.85\end{array}$ & $\begin{array}{l}\text { Based on data from Van } \\
\text { Damme et al. (2015) }\end{array}$ \\
\hline $\mathrm{A} 4$ & Higher initial prevalence on carcasses & $\mathrm{P}_{\text {initial }}$ & 37.5 & Van Damme et al. (2015) \\
\hline A5 & Higher initial concentration on carcasses & $\mathrm{C}_{\text {initial }}$ & $\begin{array}{l}\sim \text { Normal }(-2.065 ; 0.736) \text { truncated at a } \\
\text { minimum value of }-1.85\end{array}$ & $\begin{array}{l}\text { Based on data from Van } \\
\text { Damme et al. (2015) }\end{array}$ \\
\hline \multirow[t]{2}{*}{ A6 } & \multirow[t]{2}{*}{ Higher initial prevalence and concentration on carcasses } & $\mathrm{P}_{\text {initial }}$ & 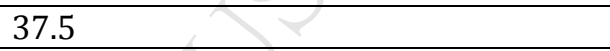 & Van Damme et al. (2015) \\
\hline & & $\mathrm{C}_{\text {initial }}$ & $\begin{array}{l}\sim \text { Normal }(-2.065 ; 0.736) \text { truncated at a } \\
\text { minimum value of }-1.85\end{array}$ & $\begin{array}{l}\text { Based on data from Van } \\
\text { Damme et al. (2015) }\end{array}$ \\
\hline A7 & Only conventional air chilling (no blast chilling) & $\mathrm{I}_{\mathrm{cc}}$ & -0.1 & King et al. (2012) \\
\hline A8 & Steam condensation followed by conventional chilling & $\mathrm{I}_{\mathrm{cc}}$ & $\sim-\operatorname{Pert}(0.7,2.2,4)-0.1$ & $\begin{array}{l}\text { Smulders et al. (2012) and King } \\
\text { et al. (2012) }\end{array}$ \\
\hline A9 & $\begin{array}{l}\text { Steam condensation followed by blast chilling and } \\
\text { conventional chilling }\end{array}$ & $\mathrm{I}_{\mathrm{cc}}$ & $\sim-\operatorname{Pert}(0.7,2.2,4)-0.6$ & $\begin{array}{l}\text { Smulders et al. (2012) and King } \\
\text { et al. (2012) }\end{array}$ \\
\hline \multirow[t]{3}{*}{ A10 } & \multirow{3}{*}{$\begin{array}{l}\text { Lactic acid treatment followed by conventional chilling and } \\
\text { cold storage }\end{array}$} & $\mathrm{I}_{\mathrm{cc}}$ & -0.7 & King et al. (2012) \\
\hline & & $\lambda_{\mathrm{ccg}}$ & 48 & van Netten et al. (1997) \\
\hline & & $\mathrm{D}_{\mathrm{ccg}}$ & 12.4 & van Netten et al. (1997) \\
\hline \multirow[t]{3}{*}{ A11 } & \multirow{3}{*}{$\begin{array}{l}\text { Lactic acid treatment followed by blast chilling and } \\
\text { conventional chilling and cold storage }\end{array}$} & $I_{c c}$ & -1.6 & King et al. (2012) \\
\hline & & $\lambda_{c c g}$ & 48 & van Netten et al. (1997) \\
\hline & & $\mathrm{D}_{\mathrm{ccg}}$ & 12.4 & van Netten et al. (1997) \\
\hline A12 & $\begin{array}{l}\text { Minced meat produced using carcasses stored over } \\
\text { weekend }\end{array}$ & Time $_{\text {ccg }}$ & $68 \mathrm{~h}$ & Company information \\
\hline A13 & $\begin{array}{l}\text { Minced meat produced using carcasses the day after } \\
\text { slaughter }\end{array}$ & Time $_{\text {ccg }}$ & $20 \mathrm{~h}$ & Company information \\
\hline
\end{tabular}


Table 4. Overview of variables and parameters to evaluate alternative scenarios during grinding.

\begin{tabular}{|c|c|c|c|c|}
\hline Scenario & Variable & Description & Alternative value/distribution/model & Source \\
\hline \multirow[t]{9}{*}{$\begin{array}{l}\text { B1-B3: } \\
\text { Addition of } \\
\text { head meat }\end{array}$} & $\mathrm{P}_{\text {initial }, \mathrm{m}}{ }^{*}$ & $\begin{array}{l}\text { Prevalence of } Y \text {. enterocolitica on pig } \\
\text { carcasses (mandibular region) after } \\
\text { evisceration }\end{array}$ & $28.89 \%$ & Van Damme et al. (2015) \\
\hline & $\mathrm{C}_{\text {initial, }}{ }^{*}$ & $\begin{array}{l}\text { Concentration of } Y \text {. enterocolitica on pig } \\
\text { carcasses (mandibular region) after } \\
\text { evisceration (positive carcasses only) }\end{array}$ & $\begin{array}{l}\sim \text { Normal }(-0.578 ; 1.256) \text { truncated at a } \\
\text { minimum of } 0.15\left(\text { in } \log _{10} \mathrm{CFU} / 100 \mathrm{~cm}^{2}\right)\end{array}$ & $\begin{array}{l}\text { Based on data from Van Damme et al. } \\
\text { (2015) }\end{array}$ \\
\hline & $\mathrm{C}_{\mathrm{mci}}{ }^{*}$ & $\begin{array}{l}\text { Concentration on pig carcasses } \\
\text { (mandibula) after inactivation during } \\
\text { chilling }\end{array}$ & $=\mathrm{C}_{\text {initial }, \mathrm{m}}+\mathrm{I}_{\mathrm{cc}}\left(\right.$ in $\left.\log 10 \mathrm{CFU} / 100 \mathrm{~cm}^{2}\right)$ & Calculation \\
\hline & $\mathrm{N}_{\mathrm{mcg}}{ }^{*}$ & $\begin{array}{l}\text { Number of } Y \text {. enterocolitica after growth } \\
\text { during cold storage }\end{array}$ & $\begin{array}{l}=10^{\mathrm{C}_{\mathrm{mci}}} \times 2^{\left(\text {Time }_{\mathrm{ccg}}-\lambda_{\mathrm{ccg}}\right) / \mathrm{D}_{\mathrm{ccg}}} \text { (in } \\
\left.\mathrm{CFU} / 100 \mathrm{~cm}^{2}\right)\end{array}$ & Calculation \\
\hline & \%headmeat* & $\begin{array}{l}\% \text { of head meat in a batch of minced meat } \\
(\mathrm{w}: \mathrm{w})\end{array}$ & $1 \%(\mathrm{~B} 1), 10 \%(\mathrm{~B} 2)$ or $50 \%(\mathrm{~B} 3)$ & Assumption \\
\hline & $\mathrm{W}_{\mathrm{hm}}{ }^{*}$ & Weight of a piece of head meat & $0.075 \mathrm{~kg}$ & Company information \\
\hline & $\mathrm{n}_{\mathrm{hb}} *$ & Number of head meat cuts per batch & $\mathrm{n}_{\mathrm{hb}}=\frac{\mathrm{W}_{\mathrm{b}} \times \% \text { headmeat }}{\mathrm{W}_{\mathrm{hm}}}$ & Calculation \\
\hline & $\mathrm{n}_{\mathrm{phb}} *$ & $\begin{array}{l}\text { Number of positive head meat cuts per } \\
\text { batch }\end{array}$ & $\sim \operatorname{Binomial}\left(\mathrm{n}_{\mathrm{hb}}, \mathrm{P}_{\text {initial }, \mathrm{m}}\right)$ & Assumption \\
\hline & $\mathrm{N}_{\mathrm{mb}}$ & $\begin{array}{l}\text { Number of } Y \text {. enterocolitica in one minced } \\
\text { meat batch }\end{array}$ & $\begin{array}{l}\mathrm{N}_{\mathrm{mb}}=\sum_{\mathrm{i}=1}^{\mathrm{n}_{\mathrm{pbb}}} \mathrm{N}_{\mathrm{bdr}, \mathrm{i}}+\sum_{\mathrm{i}=1}^{\mathrm{n}_{\mathrm{phb}}} \mathrm{N}_{\mathrm{mb}, \mathrm{i}} \text { (in } \\
\text { CFU) }\end{array}$ & Calculation \\
\hline \multirow{8}{*}{$\begin{array}{l}\text { B4-B6: } \\
\text { Addition of } \\
\text { tonsillar tissue }\end{array}$} & $\mathrm{P}_{\text {initial, }}{ }^{*}$ & $\begin{array}{l}\text { Prevalence of } Y \text {. enterocolitica in pig } \\
\text { tonsils at time of evisceration }\end{array}$ & $44.33 \%$ & Van Damme et al. (2015) \\
\hline & $\mathrm{C}_{\text {initial,t }}{ }^{*}$ & $\begin{array}{l}\text { Concentration of } Y \text {. enterocolitica in pig } \\
\text { tonsils at time of evisceration }\end{array}$ & Pert(1.00;4.00;5.91) in $\log _{10} \mathrm{CFU} / \mathrm{g}$ & $\begin{array}{l}\text { Based on data from Van Damme et al. } \\
\text { (2015) }\end{array}$ \\
\hline & $\mathrm{C}_{\mathrm{tci}} *$ & $\begin{array}{l}\text { Concentration during chilling (after } \\
\text { inactivation) }\end{array}$ & $=\mathrm{C}_{\text {initial }, \mathrm{m}}+\mathrm{I}_{\mathrm{cc}}\left(\right.$ in $\left.\log _{10} \mathrm{CFU} / \mathrm{g}\right)$ & Calculation \\
\hline & $\mathrm{N}_{\mathrm{tcg}} *$ & $\begin{array}{l}\text { Number of } Y \text {. enterocolitica after growth } \\
\text { during cold storage }\end{array}$ & $\mathrm{N}_{\mathrm{tci}} \times 2^{\left(\mathrm{Time}_{\mathrm{ccg}}-\lambda_{\mathrm{ccg}}\right) / \mathrm{D}_{\mathrm{ccg}}(\text { in CFU } / \mathrm{g})}$ & Calculation \\
\hline & $\mathrm{n}_{\mathrm{tb}} *$ & Number of tonsil pieces per batch & 1 (B4 and B5) or $10(\mathrm{~B} 6)$ & Scenarios \\
\hline & $\mathrm{W}_{\mathrm{t}}^{*}$ & Weight of a tonsil piece & $1 \mathrm{~g}(\mathrm{~B} 4$ and $\mathrm{B} 6)$ or $10 \mathrm{~g}(\mathrm{~B} 5)$ & Scenarios \\
\hline & $\mathrm{n}_{\mathrm{ptb}} *$ & Number of positive tonsil pieces per batch & $\sim \operatorname{Binomial}\left(\mathrm{n}_{\mathrm{tb}}, \mathrm{P}_{\text {initial }, \mathrm{t}}\right)$ & Calculation \\
\hline & $\mathrm{N}_{\mathrm{mb}}$ & $\begin{array}{l}\text { Number of } Y \text {. enterocolitica in one minced } \\
\text { meat batch }\end{array}$ & $\begin{array}{l}\mathrm{N}_{\mathrm{mb}}=\sum_{\mathrm{i}=1}^{\mathrm{n}_{\mathrm{pbb}}} \mathrm{N}_{\mathrm{bdr}, \mathrm{i}}+\mathrm{W}_{\mathrm{t}} \sum_{\mathrm{i}=1}^{\mathrm{n}_{\mathrm{ptb}}} \mathrm{N}_{\mathrm{tcg}, \mathrm{i}} \text { (in } \\
\mathrm{CFU})\end{array}$ & Calculation \\
\hline B7: Smaller & $\mathrm{W}_{\mathrm{b}}$ & Weight of a batch of minced meat & $140 \mathrm{~kg}$ & Company information \\
\hline
\end{tabular}


batch of

minced meat

B8: Larger

batch of

minced meat

* new variable 
Table 5. Overview of variables and parameters to evaluate alternative scenarios at consumer level.

\begin{tabular}{|c|c|c|c|c|}
\hline Code & Description & Parameter & Value & Source \\
\hline C1-4 & $\begin{array}{l}\text { Consumer storage temperature of } 4^{\circ} \mathrm{C}, 7^{\circ} \mathrm{C}, 10^{\circ} \mathrm{C} \\
\text { or } 15^{\circ} \mathrm{C}\end{array}$ & Temp $_{\text {cg }}$ & $4^{\circ} \mathrm{C}(\mathrm{C} 1), 7^{\circ} \mathrm{C}(\mathrm{C} 2), 10^{\circ} \mathrm{C}(\mathrm{C} 3)$ or $15^{\circ} \mathrm{C}(\mathrm{C} 4)$ & Scenarios \\
\hline $\mathrm{C} 5-9$ & Consumer storage for $0,1,2,3$ or 4 days & Time $_{\text {cg }}$ & $\begin{array}{l}0 \text { days (C5), } 1 \text { day (C6), } 2 \text { days (C7), } 3 \text { days (C8) or } 4 \\
\text { days (C9) }\end{array}$ & Scenarios \\
\hline \multirow[t]{2}{*}{$\begin{array}{l}\text { C1-9 at ambient } \\
\text { atmosphere }\end{array}$} & \multirow[t]{2}{*}{ Storage at ambient atmosphere } & $\mu_{\max , \mathrm{rg}}$ & $\begin{array}{l}0.0004 \times \mathrm{Temp}_{\mathrm{rg}}{ }^{2}+0.0012 \times \mathrm{Temp}_{\mathrm{rg}}+0.0174 \text { (in } \\
\left.\log _{10} \mathrm{CFU} / \mathrm{h}\right)\end{array}$ & ComBase \\
\hline & & $\mu_{\max , \mathrm{cg}}$ & $\begin{array}{l}0.0004 \times \mathrm{Temp}_{\mathrm{cg}}{ }^{2}+0.0012 \times \mathrm{Temp}_{\mathrm{cg}}+0.0174 \text { (in } \\
\left.\log _{10} \mathrm{CFU} / \mathrm{h}\right)\end{array}$ & ComBase \\
\hline C10 & Consumer storage until the use-by date & Time $_{\text {cg }}$ & 7 days & $\begin{array}{l}\text { Company } \\
\text { info }\end{array}$ \\
\hline \multirow[t]{2}{*}{ C11 } & \multirow[t]{2}{*}{ Purchase and consumption at use-by-date } & Time $_{\text {rg }}$ & 9 days & $\begin{array}{l}\text { Company } \\
\text { info }\end{array}$ \\
\hline & & Time $_{\mathrm{cg}}$ & 0 days & Assumption \\
\hline
\end{tabular}




\section{ACCEPTED MANUSCRIPT}

Table 6. Overview of the variables and parameters to evaluate uncertainty.

\begin{tabular}{|c|c|c|c|}
\hline Code & Variable & Alternative value/distribution & Source \\
\hline $\mathrm{U} 1$ & $\mathrm{C}_{\text {initial }}$ & $\sim \operatorname{Normal}(-2.065 ; 0.736)\left(\right.$ in $\left.\log _{10} \mathrm{CFU} / \mathrm{cm}^{2}\right)$ & Assumption \\
\hline $\mathrm{U} 2$ & $\mathrm{C}_{\text {initial }}$ & $\sim \operatorname{Normal}(-3.065 ; 0.736)\left(\right.$ in $\left.\log _{10} \mathrm{CFU} / \mathrm{cm}^{2}\right)$ & Assumption \\
\hline U3 & $\mathrm{C}_{\text {initial }}$ & $\sim \operatorname{Normal}(-2.565 ; 1.236)\left(\right.$ in $\left.\log _{10} \mathrm{CFU} / \mathrm{cm}^{2}\right)$ & Assumption \\
\hline $\mathrm{U} 4$ & $\mathrm{C}_{\text {initial }}$ & $\sim \operatorname{Normal}(-2.565 ; 0.236)\left(\right.$ in $\left.\log _{10} \mathrm{CFU} / \mathrm{cm}^{2}\right)$ & Assumption \\
\hline U5 & $P_{\text {initial }}$ & $23.1 \%$ & Van Damme et al. (2015) \\
\hline U6 & $\mathrm{P}_{\text {initial }}$ & $13.3 \%$ & Van Damme et al. (2015) \\
\hline $\mathrm{U} 7$ & $\mathrm{I}_{\mathrm{cc}}$ & $-0.03 \log _{10}$ reduction & El-Zawahry and Grecz (1981) \\
\hline U8 & $I_{c c}$ & $-0.8 \log _{10}$ reduction & King et al. (2012) \\
\hline U9 & $\mathrm{L}_{\mathrm{ccg}}$ & $77 \mathrm{~h}$ & Greer and Dilts (1995) \\
\hline \multirow[t]{2}{*}{ U10 } & $\mathrm{L}_{\mathrm{ccg}}$ & $0 \mathrm{~h}$ & Greer and Dilts (1995) \\
\hline & $\mathrm{D}_{\mathrm{ccg}}$ & $10.36 \mathrm{~h}$ & ComBase \\
\hline U11 & $\mathrm{R}_{\mathrm{bd}}$ & $25 \%$ & Assumption \\
\hline U12 & $\mathrm{R}_{\mathrm{bd}}$ & $75 \%$ & Assumption \\
\hline $\mathrm{U} 13$ & $\mathrm{~W}_{\mathrm{b}}$ & $850 \mathrm{~kg}$ & Assumption \\
\hline U14 & $\mathrm{W}_{\mathrm{b}}$ & $950 \mathrm{~kg}$ & Assumption \\
\hline U15 & \%bellies & $29 \%$ & Assumption \\
\hline U16 & \%bellies & $39 \%$ & Assumption \\
\hline U17 & $\mathrm{W}_{\mathrm{bdr}}$ & $7 \mathrm{~kg}$ & Assumption \\
\hline U18 & $\mathrm{W}_{\mathrm{bdr}}$ & $8 \mathrm{~kg}$ & Assumption \\
\hline U19 & Temp $p_{\mathrm{rg}}$ & $2 \quad$ & Assumption \\
\hline $\mathrm{U} 20$ & Temp $p_{\mathrm{rg}}$ & 2 & Assumption \\
\hline U21 & Timer $_{\mathrm{rg}}$ & $1 \mathrm{~d}$ & Assumption \\
\hline U22 & Time $_{\text {rg }}$ & 80 & Assumption \\
\hline \multirow[t]{3}{*}{$\mathrm{U} 23$} & \multirow[t]{2}{*}{$\mu_{\text {max,rg }}$} & $0.0003 \times \mathrm{Temp}_{\mathrm{rg}}{ }^{2}+0.0005 \times \mathrm{Temp}_{\mathrm{rg}}+0.0103$ & Assumption \\
\hline & & 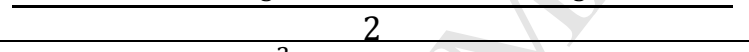 & \\
\hline & $\mu_{\text {max,cg }}$ & $\frac{0.0003 \times \mathrm{Temp}_{\mathrm{cg}}{ }^{2}+0.0005 \times \mathrm{Temp}_{\mathrm{cg}}+0.0103}{2}$ & Assumption \\
\hline
\end{tabular}


Figure 1

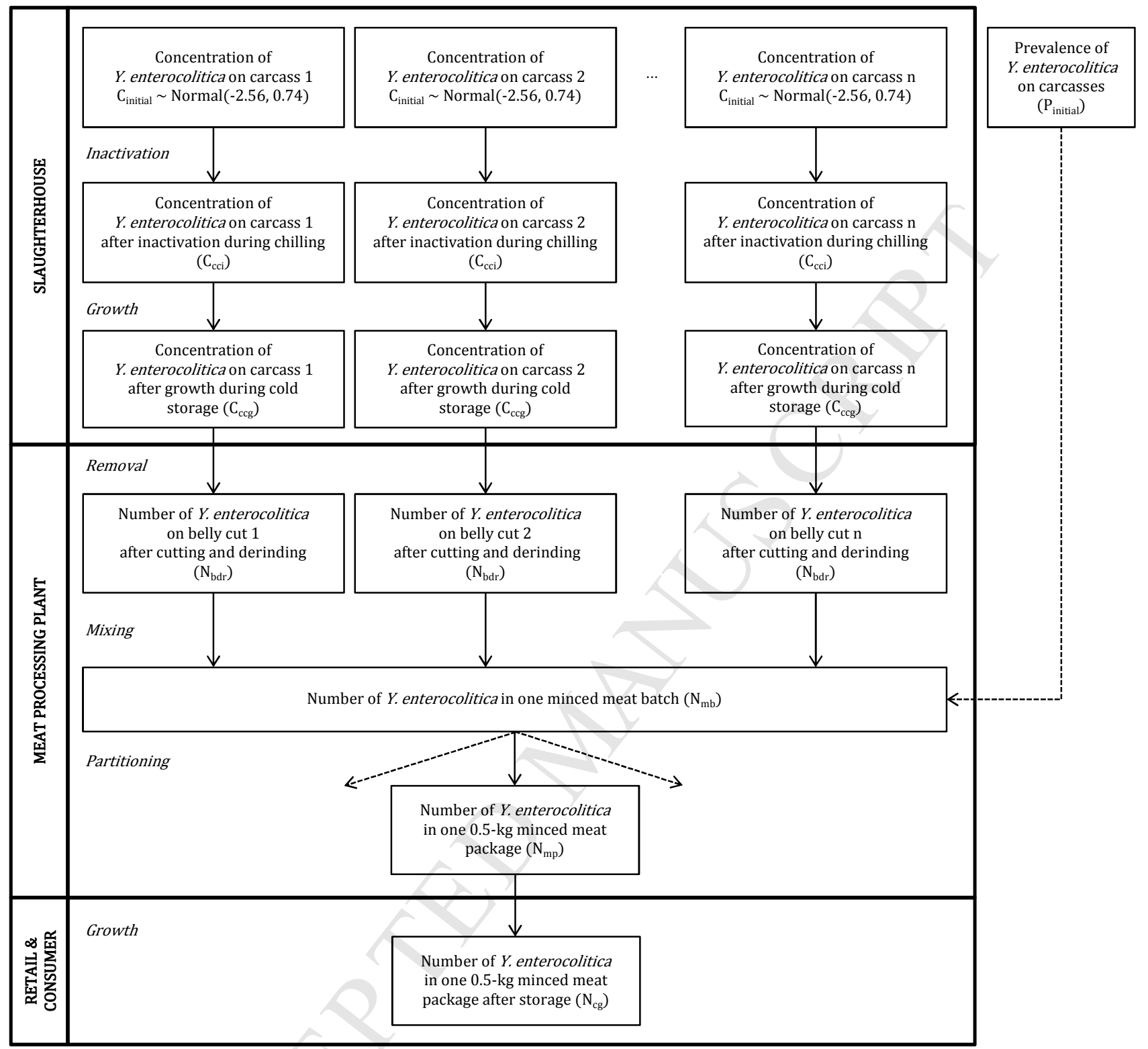


Figure 2

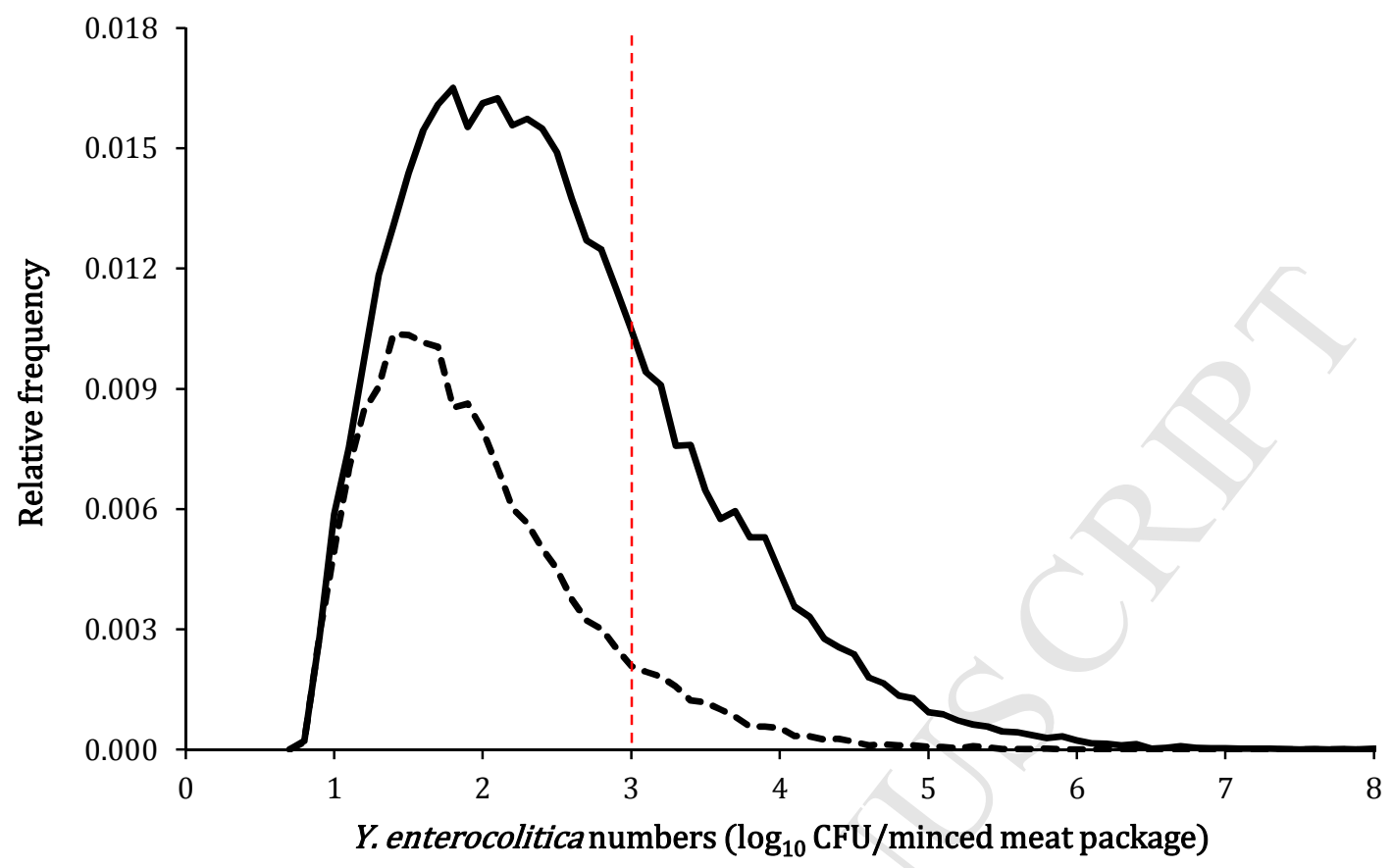


Figure 3

Relative proportion ( $\log _{10}$ transformed) of

$Y$. enterocolitica positive $0.5-\mathrm{kg}$ minced meat packages
$-0.8$
$-0.6$
$-0.4 \quad-0.2$
0
0.2
$0.4 \quad 0.6$

\section{BASELINE}

Prevalence is lower (7.5\%) and concentration is normal Prevalence is normal (16.4\%) and concentration 0.5 log lower Prevalence is lower (7.5\%) and concentration is 0.5 log lower

Prevalence is higher (37.5\%) and concentration is normal Prevalence is normal (16.4\%) and concentration is 0.5 log higher Prevalence is higher (37.5\%) and concentration is 0.5 log higher

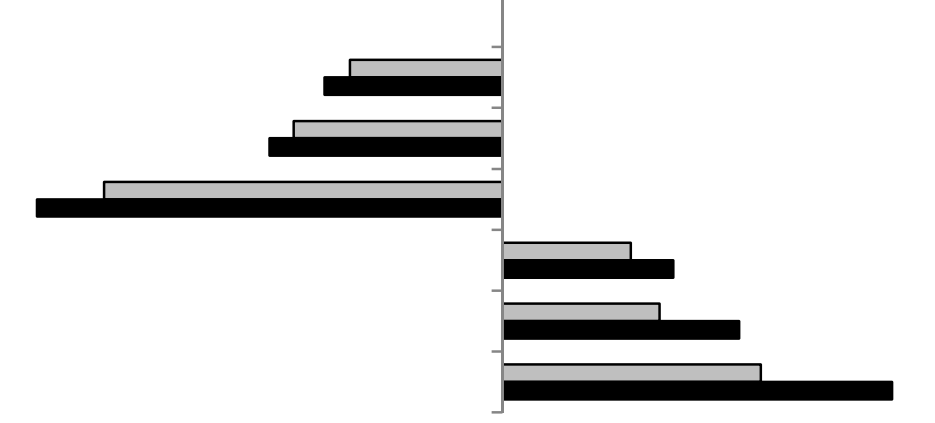


Figure 4

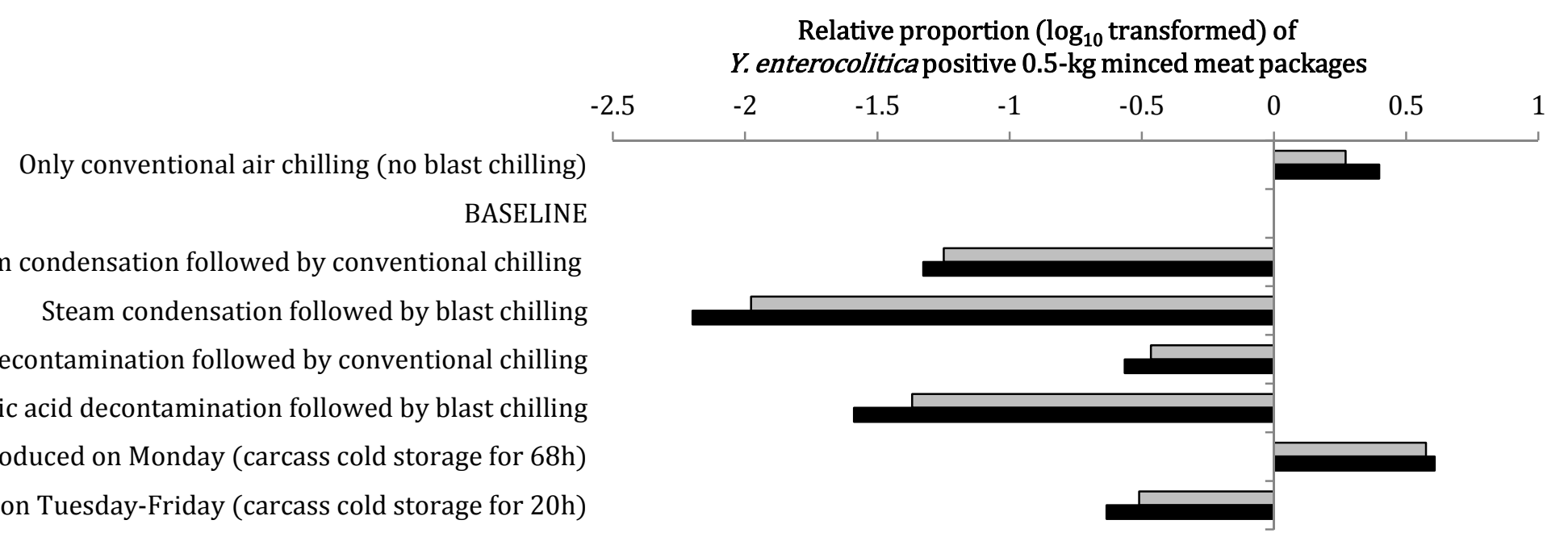

Minced meat produced on Tuesday-Friday (carcass cold storage for 20h) 


\section{Figure 5}

Relative proportion ( $\log _{10}$ transformed) of $Y$. enterocolitica positive $0.5-\mathrm{kg}$ minced meat packages

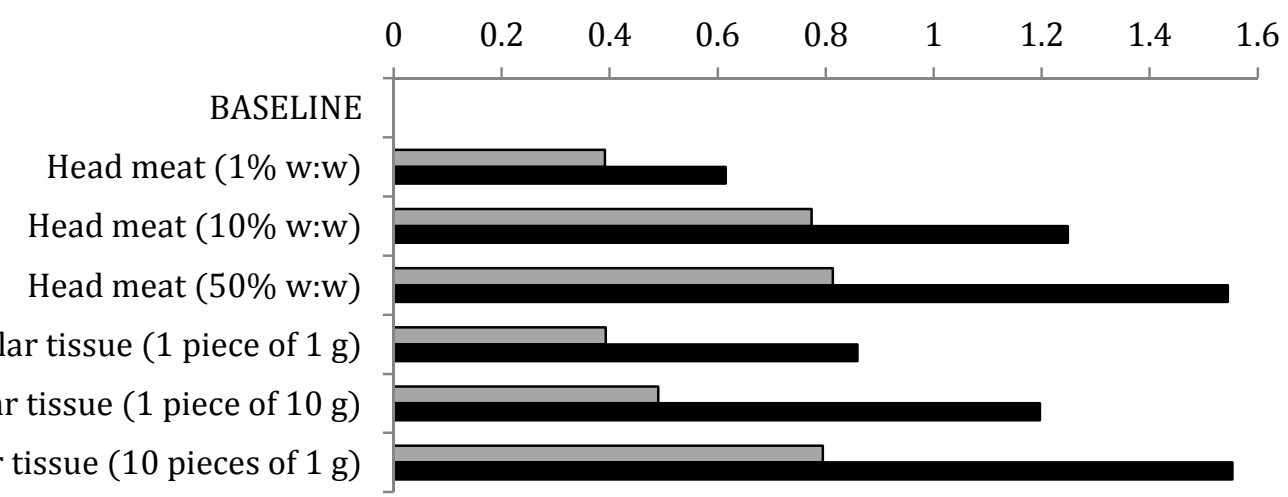

Tonsillar tissue (1 piece of $1 \mathrm{~g}$ )

Tonsillar tissue (1 piece of $10 \mathrm{~g}$ )

Tonsillar tissue (10 pieces of $1 \mathrm{~g}$ ) 


\section{Figure 6}

Relative proportion ( $\log _{10}$ transformed) of $Y$. enterocolitica positive $0,5-\mathrm{kg}$ minced meat packages

Baseline
$-3$ $-2$ Baseline
Consumer storage temperature of $4^{\circ} \mathrm{C}$
Consumer storage temperature of $7^{\circ} \mathrm{C}$ (n) Consumer storage temperature of $10^{\circ} \mathrm{C}$ Consumer storage temperature of $15^{\circ} \mathrm{C}$

Consumer storage for 0 days Consumer storage for 1 day Consumer storage for 2 days Consumer storage for 3 days Consumer storage for 4 days Consumer storage until use-by date* Purchase and consumption at use-by date* 


\section{Figure 7}

Relative proportion ( $\log _{10}$ transformed) of

Y. enterocolitica contaminated $0.5-\mathrm{kg}$ minced meat packages

$-1.5$

$-1$

$-0.5$

0

0.5

U1 - mean Cinitial is higher

U2 - mean Cinitial is lower

U3 - standard deviation Cinitial is higher

U4 - standard deviation Cinitial is lower

U5 - Pinitial is higher (23.1\%)

U6 - Pinitial is lower (13.3\%)

U7 - blast chilling results in a lower reduction

U8 - blast chilling results in a higher reduction

U9 - no growth during carcass cold storage (lean pork tissue)

U10 - increased growth during carcass cold storage (fat tissue)

U11 - higher reduction during cutting/derinding (25\% remains)

U12 - lower reduction during cutting/derinding (75\% remains)

$\mathrm{U} 13$ - lower weight of a minced meat batch $(\mathrm{Wb}=850 \mathrm{~kg})$

$\mathrm{U} 14$ - higher weight of a minced meat batch $(\mathrm{Wb}=950 \mathrm{~kg})$

U15 - less bellies (29\%, w:w)

U16 - more bellies (39\%, w:w)

$\mathrm{U} 17$ - lower weight of a belly cut (Wbdr $=7 \mathrm{~kg})$

U18 - higher weight of a belly cut (Wbdr $=8 \mathrm{~kg})$

$\mathrm{U} 19$ - lower temperature at retail $\left(\mathrm{Temprg}=2^{\circ} \mathrm{C}\right)$

$\mathrm{U} 20$ - higher temperature at retail $\left(\mathrm{Temprg}=6^{\circ} \mathrm{C}\right)$

$\mathrm{U} 21$ - shorter time at retail (Timerg $=1$ day)

U22 - longer time at retail (Timerg $=3$ days)

U23 - less growth in minced meat ( $\mu$ max is reduced by half) 


\section{Highlights}

- Contamination of minced meat with human pathogenic $Y$. enterocolitica was modelled.

- The endpoint of the assessment was the proportion of (highly) contaminated packages.

- Control of $Y$. enterocolitica contamination at slaughterhouse level is important.

- Pork bellies are preferred over head meat for the production of minced meat.

- Consumer practices strongly influence the number of highly contaminated packages. 